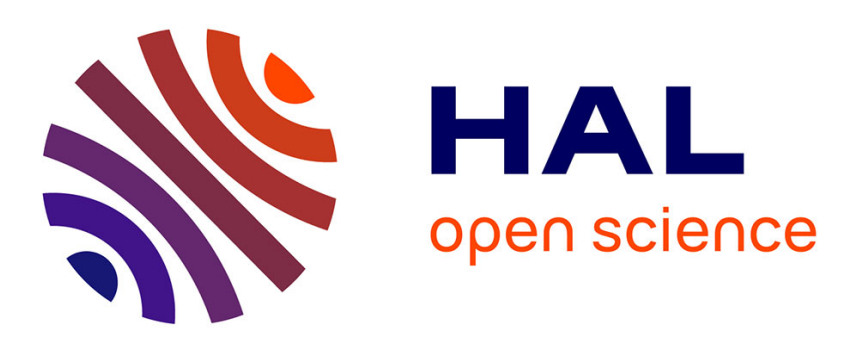

\title{
Severe convection in the Mediterranean from microwave observations and a convection-permitting model
}

Jean-François Rysman, Chantal Claud, Jean-Pierre Chaboureau, Julien Delanoë, Beatriz M. Funatsu

\section{- To cite this version:}

Jean-François Rysman, Chantal Claud, Jean-Pierre Chaboureau, Julien Delanoë, Beatriz M. Funatsu. Severe convection in the Mediterranean from microwave observations and a convectionpermitting model. Quarterly Journal of the Royal Meteorological Society, 2016, 142 (S1), pp.43-55. 10.1002/qj.2611 . hal-01198693

\section{HAL Id: hal-01198693 https: / hal.sorbonne-universite.fr/hal-01198693}

Submitted on 14 Sep 2015

HAL is a multi-disciplinary open access archive for the deposit and dissemination of scientific research documents, whether they are published or not. The documents may come from teaching and research institutions in France or abroad, or from public or private research centers.
L'archive ouverte pluridisciplinaire HAL, est destinée au dépôt et à la diffusion de documents scientifiques de niveau recherche, publiés ou non, émanant des établissements d'enseignement et de recherche français ou étrangers, des laboratoires publics ou privés. 


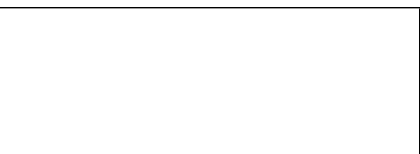

\title{
Severe convection in the Mediterranean from microwave observations and a convection-permitting model
}

\author{
Jean-François Rysman, ${ }^{\mathrm{a} *}$ Chantal Claud, ${ }^{\mathrm{a}}$ Jean-Pierre Chaboureau, ${ }^{\mathrm{b}}$ Julien Delanoë, ${ }^{\mathrm{c}}$ and \\ Beatriz M. Funatsu ${ }^{d}$ \\ a Laboratoire de Météorologie Dynamique, UPMC Univ. Paris 06, \\ ${ }^{\mathrm{b}}$ Laboratoire d'Aérologie, Université de Toulouse and CNRS, France, \\ ${ }^{c}$ Université Versailles St-Quentin; CNRS/INSU, LATMOS-IPSL, \\ ${ }^{\mathrm{d}}$ CNRS, LETG-Rennes-COSTEL, UMR 6554, Université Rennes 2
}

${ }^{*}$ Correspondence to: jfrysman@1md.polytechnique.fr 
This study investigates severe convection in the Mediterranean during the first Special Observation Period (SOP-1; 5 September-6 November 2012) of the Hydrological Cycle in the Mediterranean Experiment (HyMeX) with the objectives of providing novel information about severe convection on its vertical structure, spatio-temporal variability as well as evaluating the ability of a convection-permitting model to reproduce this variability. Two criteria, namely deep convection (DC) and convective overshooting (COV), are computed using the water vapour channels of the Microwave Humidity Sounder (MHS). Special attention is paid to the COV as it is associated with particularly severe weather. For the first time, the COV criterion was assessed in the Mediterranean, using two case studies conjointly observed by the airborne Rasta radar and MHS. $\mathrm{COV}$ is characterised by high ice water content (up to $2 \mathrm{g.m}^{-3}$ ) in the mid and upper troposphere (up to $12.5 \mathrm{~km}$ in the stratosphere).During the SOP1, DC and COV occurred about $0.1 \%$ and $0.03 \%$ of the total observation time, respectively. The Atlantic weather regimes appear to affect the temporal distribution of these convective events. Most of the DC and COV occurrences were found along the western coasts of Italy and Greece, mainly during the 10-15 October and 25 October-3 November episodes. These two episodes, for which severe meteorological events (e.g., tornadoes) were reported, are significant when compared with the 2002-2013 climatology (above the 75th percentile). Both criterions are also employed to assess the current ability of the Meso-NH model to forecast severe convection using a model-to-satellite approach. The forecasted DC and COV are found to be highly correlated in time with the observations, but are strongly underestimated. This suggests that the model missed a significant part of the most intense convective events and their associated hazards and underlines the need for better characterisation of model uncertainties associated with severe convection. 
Key Words: Convection-permitting model, Convective Overshooting, Deep Convection, HyMeX SOP-1, Mediterranean region, Microwave Observations

\section{Introduction}

The Mediterranean region is frequently affected by intense meteorological events such as heavy precipitation and flash floods as well as occasional but potentially devastating tropical-like cyclones (Papagiannaki et al. 2013; Tous and Romero 2013; Trigo et al. 2002; Lionello et al. 2006; Claud et al. 2010). These events mostly occur during the autumn season over the western Mediterranean basin (Melani et al. 2013; Ducrocq et al. 2014; Raveh-Rubin and Wernli 2015). Because of the high population density (more than 500 people per $\mathrm{km}^{2}$ in some regions), they often cause significant societal damage, for example, there were more than 800 casualties during the Algiers floods in 2001. In particular, deep convective systems (DC) can accumulate considerable volumes of rain over a region in only a few hours, e.g., Genoa in October 1970 (Roth et al. 1996; Siccardi 1996), Vaison-la-Romaine in September 1992 (Sénési et al. 1996), Izmir in November 1995 (Kömüşçü 1998), Algiers in November 2001 (Argence et al. 2008), Gard in September 2002 (Delrieu et al. 2005; Ducrocq et al. 2008), eastern coasts of Greece in January 2004 (Lagouvardos et al. 2007), Draguignan in June 2010 (Fresnay 2014) and, Nice-Genoa in November 2011 (Silvestro et al. 2012; Rebora et al. 2013; Buzzi et al. 2014). A special class of DC events called convective overshooting (COV) has been known for a long time to be associated with particularly severe weather such as heavy rainfall, damaging winds, hail, and tornadoes in the United States (Reynolds 1980; Negri and Adler 1981; Adler et al. 1985; Brunner et al. 2007) and Europe (including the Mediterranean region; Bedka (2011)). Moreover, Hong et al. (2008) showed in a climatological analysis from $30^{\circ} \mathrm{S}$ to $30^{\circ} \mathrm{N}$ that COV tends to be more frequent over land (e.g., tropical Africa and South America) than over ocean and presents a strong seasonal variability. COV are associated with very intense updrafts, so that convection reaches the tropopause and penetrates into the lower stratosphere. They 
occur within convective systems that can have large spatial and temporal extension (several hours and more than $100 \mathrm{~km}$,

Orlanski 1975). No clear consensus exists about the exact life time and size of COV but they are assumed to have a small diameter compared to convective systems in the order of several tens of kilometres and duration in the order of several tens of minutes. Within overshooting clouds, clusters $<15 \mathrm{~km}$ in diameter of very low brightness temperatures were observed in the infrared imagery for several minutes ( $<15$ min) (Bedka 2011; Bedka et al. 2012). These small phenomena (several tens of kilometers and several tens of minutes) are difficult to forecast and therefore there is a need for better detection and understanding. An improved forecast should lead to a better mitigation of the associated damage, having a high societal impact.

In this context, the international project, the Hydrological cycle in the Mediterranean Experiment (HyMeX) was launched in 2010 to gain a better understanding of hydrological cycle and heavy precipitation events in the whole Mediterranean region (Drobinski et al. 2014). The first Special Observation Period (SOP-1) of HyMeX took place in the north-western Mediterranean Sea and surrounding regions from 5 September 2012 to 6 November 2012 (Ducrocq et al. 2014). More than 150 research instruments such as radars, lidars, raingauges, electric field sensors and meteorological balloons were deployed during this major field campaign. Three aircraft also participated in the SOP-1 with on-board instruments such as microphysical in-situ probes, cloud radar and differential absorption lidar (for details see Ducrocq et al. 2014; Ferretti et al. 2014). In addition to research instruments specially dedicated to the HyMeX SOP-1, spaceborne instruments (e.g., Microwave Humidity Sounder (MHS); Bonsignori (2007), Meteosat Second Generation (MSG) Spinning Enhanced Visible and InfraRed Imager (SEVIRI); Schmetz et al. (2002)) and operational ground-based networks also provided information about the meteorological environment of the Mediterranean region during this period. In this study, we use observations from the passive microwave sounder MHS to identify deep convection (DC) and convective overshooting (COV) occurrences. This instrument covers a wide area with a swath of $1920 \mathrm{~km}$ with a fairly fine pixel resolution (16 km at nadir). Such a spatial resolution is fine enough to observe DC and COV events as shown by Hong et al. (2005). Yet the finest convective towers highlighted in Bedka (2011); Bedka et al. (2012) are probably missed. MHS 
also provides observations over the sea where available data are scarce. During the HyMeX SOP-1, MHS flew on-board three polar orbiting satellites each of them flying over the Mediterranean basin twice a day with different crossing times.

Hong et al. (2005) developed a method to detect the occurrence of deep convection and convective overshooting over the Tropics using water vapour channels of the AMSU-B (Advanced Microwave Sounding Unit) module that is quasisimilar to the MHS module. This innovative method uses a threshold on the brightness temperature differences between the three channels to detect DC and a more stringent relation between brightness temperature differences to detect COV. These DC and COV criteria have been used so far for tropical regions (Hong et al. 2008; Funatsu et al. 2012; Aumann and Ruzmaikin 2013), while only DC criterion has been applied in the Mediterranean region (e.g., Funatsu et al. 2007, 2008, 2009; Claud et al. 2012; Alhammoud et al. 2014; Sanò et al. 2015). Here, we take advantage of the airborne radar measurements performed during the HyMeX SOP-1 to evaluate the COV criterion in the Mediterranean region for the first time. Moreover, this study provides the first-ever characterisation of COV in terms of frozen hydrometeor content and diameter. Then, we use both DC and COV criteria to provide an estimation of the spatial and temporal distribution of severe convection during the HyMeX SOP-1. This characterisation can be used for validating simulations by convectionpermitting models as will be illustrated for the Meso-NH model (Lafore et al. 1998).

The paper is organised as follows. In the section 2, we describe the instruments and the method. Since the method was developed for tropical convective systems and for the AMSU-B radiometer, the validity of the Hong et al. (2005) criteria for the Mediterranean region and for the MHS radiometer is assessed in section 3. In section 4, we document the occurrence of DC and COV during the HyMeX SOP-1 and we compare this period to the previous 10 years of AMSUB/MHS measurements. Section 5 is dedicated to the assessment of the Meso-NH model to accurately forecast severe convection. The discussion and conclusions are presented in section 6. 


\section{Data and Method}

\subsection{Microwave Humidity Sounder (MHS)}

DC and COV detection and characterisation are achieved using space-borne MHS measurements. MHS is a cross-scanning radiometer primarily designed for water vapour atmospheric profile retrieving. It measures upwelling microwave radiation using five channels: two window channels at 89 and $157 \mathrm{GHz}$ (not used in this study) and three channels in the water vapour absorption line (at $183.3 \pm 1,183.3 \pm 3$ and $190.3 \mathrm{GHz}$ ). These three channels probe more or less deeply into the atmosphere depending on their frequencies. The swath width of MHS is $1920 \mathrm{~km}$, the nadir resolution is $16 \mathrm{~km}$ and the viewing angle ranges from $0.6^{\circ}$ to $60^{\circ}$.

During the HyMeX SOP-1, three MHS radiometers on-board the polar orbiting satellites National Oceanic and Atmospheric Administration (NOAA) satellites NOAA-18, NOAA-19 and the European Operational Meteorological satellite MetOp-A respectively, were available. These satellites have synchronous orbits and fly over the Mediterranean region twice a day: 02:00-05:00 and 13:00-16:00 for NOAA-18, 23:00-02:00 and 10:00-13:00 for NOAA-19, and 07:0010:00 and 18:00-21:00 UTC for MetOp-A.

Hong et al. (2005) developed a method to detect both deep convection and convective overshooting events using the AMSU-B radiometer that is quasi-similar to the MHS radiometer (for a comparison, see Claud et al. 2012). Using a microwave radiometer and an X-band radar on-board a scientific aircraft, they found that for clear sky conditions, brightness temperature measured by each water vapour channel is always higher for channels with frequencies further away from the centre frequency at $183.3 \mathrm{GHz}$, but within convective clouds this relationship is reversed. This is because channels further away from the centre at $183.3 \mathrm{GHz}$ can probe deeper into the clouds. Consequently, those channels are more subject to scattering by hydrometeors from the middle or low layers of the deep convective clouds (Burns et al. 1997; Wang et al. 1997), which depresses the observed brightness temperatures. Moreover, Hong et al. (2005) showed that close to the convective core, the brightness temperatures difference between channels tends to be close to zero while 
it remains higher for higher frequencies where the convective cloud penetrates the tropopause layer. The reason is that the temperature weighting functions of the three water vapour channels tend to be similar where there is a large frozen hydrometeor content (Burns et al. 1997). As a result, Hong et al. (2005) established two criteria to detect deep convection and convective overshooting using these frequencies.

Deep convection is detected whenever:

$$
\begin{array}{r}
T B_{3}-T B_{5} \geq T_{0} \\
\text { and } T B_{3}-T B_{4} \geq T_{0} \\
\text { and } T B_{4}-T B_{5} \geq T_{0}
\end{array}
$$

with $T_{0}=0.04761-0.01678 \theta+0.00599 \theta^{2}$ where $\theta$ is the viewing angle, and $T B_{3-5}$ are brightness temperatures for channels 3-5 (i.e., $183.3 \pm 1,183.3 \pm 3$ and $190.3 \mathrm{GHz}$ )

Convective overshooting is detected where:

$$
T B_{3}-T B_{5} \geq T B_{3}-T B_{4} \geq T B_{4}-T B_{5}>T_{1}
$$

Using simulations and a microwave radiative transfer model, Hong et al. (2005) showed that the COV criterion performs better when $\theta \leq 35^{\circ}$. For $\theta \leq 30^{\circ}, T_{1}=0 \mathrm{~K}$ and for $35^{\circ} \geq \theta>30^{\circ}, T_{1}=7 \mathrm{~K}$. Because COV occur within DC systems, the DC criterion is also fulfilled every time the COV criterion is reached.

It must be noted that these criteria have been established for tropical conditions and using AMSU-B channel frequencies $(183.3 \pm 1,183.3 \pm 3$ and $183.3 \pm 7 \mathrm{GHz})$ that are slightly different from MHS channels frequencies. In the Mediterranean region, Funatsu et al. (2007) showed that DC events correspond to a TRMM 3B42 3-hour accumulated rainfall product of at least $20 \mathrm{~mm}$ in $50 \%$ of the cases. In this paper, we evaluate both the DC and COV criteria in the Mediterranean region 
$\left(10^{\circ} \mathrm{W}-35^{\circ} \mathrm{E}\right.$ and $\left.32^{\circ} \mathrm{N}-48^{\circ} \mathrm{N}\right)$ using vertical profiles of reflectivity completed during the HyMeX SOP-1 by an airborne radar.

\subsection{Rasta}

Rasta (RAdar SysTem Airborne) is an airborne $95 \mathrm{GHz}$ Doppler cloud radar (Protat et al. 2004; Bouniol et al. 2008;

Protat et al. 2009; Delanoë et al. 2013; Bousquet and Smull 2006). It measures reflectivity using six antennas: three pointing downwards in three non-collinear directions, including one nadir pointing angle, and three pointing upwards in three non-collinear directions, including one zenith pointing angle. The vertical resolution is $60 \mathrm{~m}$ and the temporal resolution is 1.25 seconds. The minimal detectable cloud reflectivity is about $-35 \mathrm{dBZ}$ depending on the antenna, and the calibration accuracy is about 1-2 dB. This instrument makes it possible to investigate microphysical properties of clouds (e.g., Delanoë et al. 2013) since it detects hydrometeor sizing from about a hundred microns to a few millimetres. Mean volume-weighted diameter of frozen hydrometeors and ice water content were retrieved at each radar gate (i.e., $60 \mathrm{~m}$ ) using the radonvar method (adapted from Delanoë et al. 2007, 2014). The retrieval error is estimated to be within $30 \%$, a first evaluation having been carried out using collocated in-situ data such as particle size and bulk measurements. During the HyMeX campaign, Rasta was mounted on the Falcon 20 aircraft which carried out 18 flights (about 50 flying hours). Because the mission of the aircraft was to fly close to the convective systems, Rasta provided unique measurements to evaluate the COV criterion.

\section{Evaluation of COV criterion}

During the HyMeX SOP-1, two COV events were observed near concomitantly by MHS and Rasta instruments, with measurements within 10 minutes and $10 \mathrm{~km}$ apart. These nearly coincidental observations allowed us to evaluate the COV criterion for the first time in the Mediterranean. Analysis of Rasta-derived products provides unique information about the content and mean diameter of the frozen hydrometeors associated with COV. Note that a complete meteorological analysis of these two cases is beyond the scope of this paper 


\subsection{October Case}

The 20 October case corresponds to the Intensive observation period (IOP) 15a (Ducrocq et al. 2014). The synoptic situation was characterised by a north-south elongated trough located along Portugal that slowly evolved to a cut-off low. This situation triggered strong frontal convergence and warm advection over western Spain. Overall the event triggered $149 \mathrm{~mm}$ of rain in $24 \mathrm{~h}$ over Spain and caused flooding in the Ebro Basin (shown in Figure 1 (Top)).

Figure 1 shows DC and COV occurrence derived from MHS at 14:18 UTC on 20 October 2012 (Top), brightness temperatures from MHS (Middle) and reflectivity profiles from Rasta (Bottom) between 14:23 and 14:35 UTC (flight 23 of the Falcon 20 aircraft). At 14:18 UTC, the MSG $10.8 \mu$ m channel showed brightness temperatures down to $203 \mathrm{~K}$ over the northeastern part of Spain, highlighting a convective region. A secondary region of convective activity with brightness temperatures down to $220 \mathrm{~K}$ was found along the Spanish foothills of the Pyrenees. In the following study, we focused our analysis on the deepest system, centred at $0^{\circ} \mathrm{W}-41.5^{\circ} \mathrm{N}$. For this system, MHS observations highlight a deep convective region of approximately $140 \mathrm{~km}^{2}$ (9 pixels), in which an area of $80 \mathrm{~km}^{2}$ (5 pixels) of COV tops is detected.

At 14:25 UTC, the Falcon 20 aircraft entered the cloud system, characterised by reflectivity higher than -35 dBZ (i.e., Rasta sensitivity), and came out at 14:33 UTC. This system showed the typical anvil shape and could be separated into several segments using vertical profiles of reflectivity (Figure 1 (Bottom)), mean diameter and mass content of frozen hydrometeors (Figure 2). In the first segment, from 14:24.5 to 14:25.3 UTC (1), cloud tops exceeded $12.5 \mathrm{~km}$. The reflectivity ranged from $-30 \mathrm{dBZ}$ to $0 \mathrm{dBZ}$ at altitudes $>10 \mathrm{~km}$ and lower than $-35 \mathrm{dBZ}$ below. As the aircraft moved further into the cloud (14:25.3-14.25.8 UTC (2))), the reflectivity increased up to $5 \mathrm{dBZ}$ above $10 \mathrm{~km}$ and surpassed $10 \mathrm{dBZ}$ in the layer from $4 \mathrm{~km}$ to $9 \mathrm{~km}$. Retrievals based on Rasta indicated that the mean diameter of frozen hydrometeors ranged from $0.8 \mathrm{~mm}$ at $3.8 \mathrm{~km}$ to $0.2 \mathrm{~mm}$ at $12 \mathrm{~km}$ (Figure 2 (Top)) and ice water content had a range of approximately

0.8-1 g.m $\mathrm{m}^{-3}$ from 3.5 to $6 \mathrm{~km}, 1.4-1.6 \mathrm{~g} \cdot \mathrm{m}^{-3}$ from 7 to $8 \mathrm{~km}$ and $0.1-0.2 \mathrm{~g} \cdot \mathrm{m}^{-3}$ from 8 to $12 \mathrm{~km}$ (Figure 2 (bottom)). As a result, the larger hydrometeor loading at lower levels led to larger scattering that in turn led to more depressed brightness temperatures for channels that probed deeper into the atmosphere. As a result, MHS measurements in Figure 1 (Middle) 


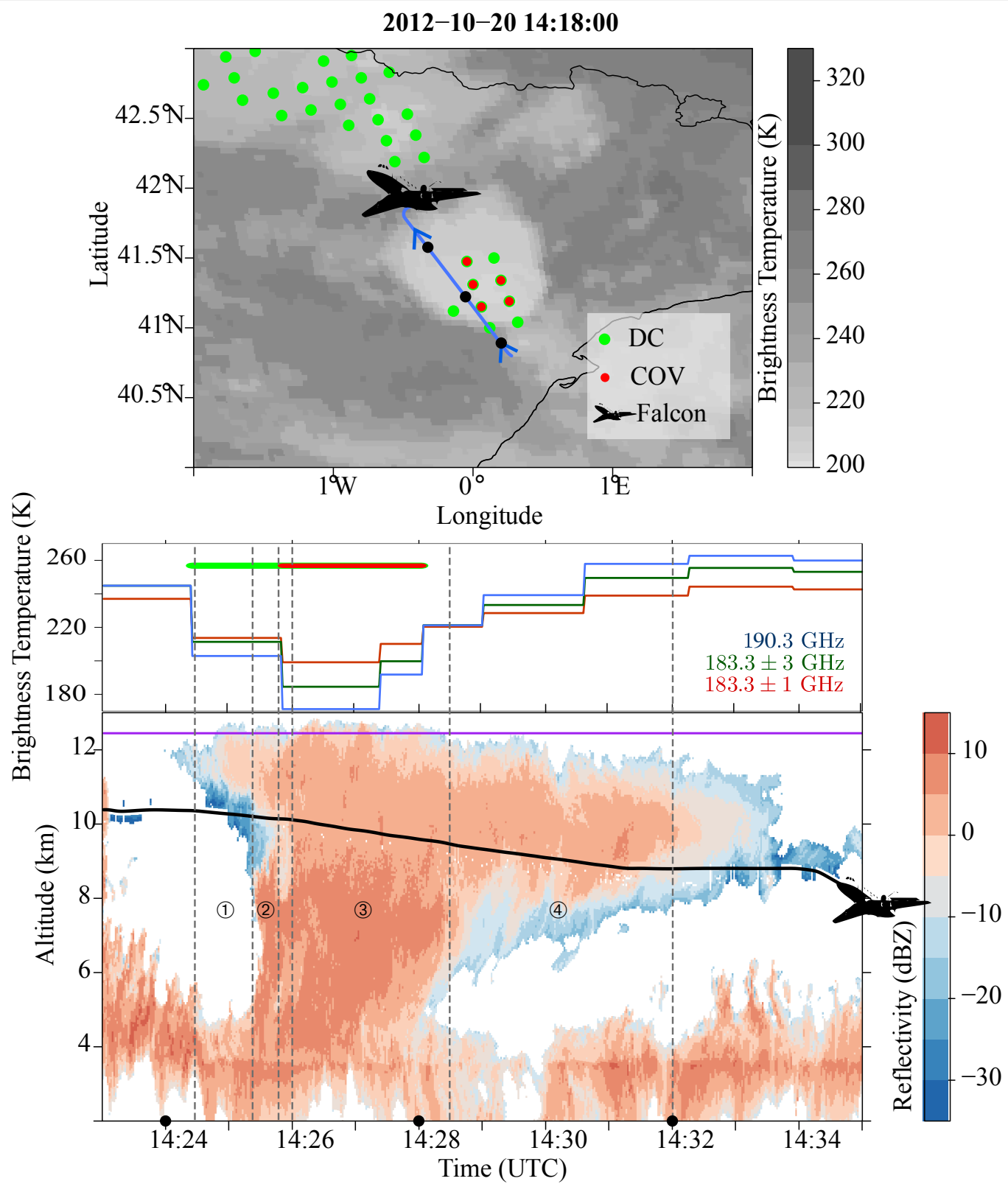

Figure 1. Case of 20 October 2012. (Top) Brightness temperatures from the MSG $10.8 \mu \mathrm{m}$ SEVIRI channel at 14:18 UTC are shown in grey levels, the track of the Falcon 20 is shown as a blue line, DC and COV are symbolised by green and red spots respectively. (Middle) Dark red (183.3 $\pm 1 \mathrm{GHz}$ ), dark green $(183.3 \pm 3 \mathrm{GHz})$ and dark blue $(190.3 \mathrm{GHz})$ lines show the MHS brightness temperatures from NOAA 18 satellite at 14:18 UTC for gridpoints that are the closest to the Rasta flight track. DC and COV are symbolised by thick green and red lines respectively. (Bottom) Reflectivity from Rasta radar is shown in colour, the track of the Falcon 20 is shown as a black line, the tropopause height is displayed with a purple line. Black dashed lines have been added to highlight several segments of the cloud that are discussed in the text. Black points are displayed along flight track at 14:24, 14:28 and 14:32 UTC.

showed lower brightness temperatures $(205 \mathrm{~K})$ for channels further away from the centre frequency at $183.3 \mathrm{GHz}$, which was the opposite of that found for clear sky conditions. DC condition (Equation 1) was satisfied in this time window (from 14:24.5 to $14: 25.8$ UTC). 
In the following segment spanning 14:26 to 14:28.5 UTC (3), the clouds also exceeded the $12.5 \mathrm{~km}$ height. Reflectivity ranged from 0 to $10 \mathrm{dBZ}$ between $4 \mathrm{~km}$ to $12 \mathrm{~km}$ and was enhanced above $8 \mathrm{~km}$ compared with the previous segment. This cloud section corresponded to the main convective part of the cloud system. Two elevated towers observed at 14:26.5 and 14:27.5 UTC presented reflectivity up to $5 \mathrm{dBZ}$ at 12-km altitude (in contrast, outside these towers reflectivity was lower than $0 \mathrm{dBZ}$ at this altitude). Similarly to the previous segment, lower brightness temperatures (for example, down to $175 \mathrm{~K}$ for channel at $190.3 \mathrm{GHz}$ ) were found for channels further away from the centre frequency at $183.3 \mathrm{GHz}$. Since their differences were found to obey the differential order relation given in Equation 2, DC and COV were identified. Microphysical characteristics help to understand why COV is detected in this particular cloud section (Figure 2). The mean diameter of frozen hydrometeors was slightly higher than in the previous segment at high levels ( 0.8 to $0.5 \mathrm{~mm}$ from 3.8 to $8 \mathrm{~km}, 0.4$ to 0.3 from 8 to $12 \mathrm{~km}$ ) but the main difference was the much more substantial ice water content between 6 and $8 \mathrm{~km}\left(1.6\right.$ to $\left.1.8 \mathrm{~g} \cdot \mathrm{m}^{-3}\right)$ and especially between 10 and $12 \mathrm{~km}$, where values ranged from 1 to $1.4 \mathrm{~g} . \mathrm{m}^{-3}$. In one elevated tower, the ice water content even reached $1.6 \mathrm{~g} \cdot \mathrm{m}^{-3}$. This very high ice water content likely explains why COV is detected in this cloud section and not in the former.

Finally, from 14:28.5 to 14:32 UTC (4), the cloud tops were less elevated (cloud tops lower than $12 \mathrm{~km}$ ) and thinner (approximately $3 \mathrm{~km}$ ) than those within the main convective region, yet they showed significant reflectivity (up to $10 \mathrm{dBZ}$ ). This was due to the rather high ice water content (up to $1.2 \mathrm{~g} \cdot \mathrm{m}^{-3}$ ) (Figure 2). Moreover the mean diameter was larger $(0.4-0.5 \mathrm{~mm})$ than in previous segments at the same altitude suggesting that hydrometeors in this segment grew during a longer period of time and probably originate from the convective part of the cloud system. MHS measurements showed that the order between the three channels was reversed compared to the previous sections: lower temperatures (230-239 K) were found for channel $183.3 \pm 1 \mathrm{GHz}$, while higher temperatures (237-252 K) are found for channel $190.3 \mathrm{GHz}$. Thus DC and COV were not detected. The flight continued after 14:32 UTC, where it reached the base of the upper-level clouds. Once again neither DC nor COV were detected. 
In order to further evaluate the $\mathrm{COV}$ detection criterion, we checked the tropopause height in Barcelona using radiosoundings. The tropopause height was determined following the World Meteorology Organisation definition of the tropopause, i.e., "The lowest level at which the lapse rate decreases to $2^{\circ} \mathrm{C}$ per $\mathrm{km}$ or less, provided that the average lapse rate between this level and all higher levels within $2 \mathrm{~km}$ does not exceed $2^{\circ} \mathrm{C}$ per $\mathrm{km}$ ". The tropopause height was estimated to be at approximately $12.5 \mathrm{~km}$ and $12.3 \mathrm{~km}$ respectively at 12:00 UTC and 18:00 UTC. Since the cloud system exceeded these altitudes in the COV-detected regions, the COV criterion was validated for this particular case.

\subsection{October Case}

The 12 October case corresponds to the IOP $12 \mathrm{~b}$ (Ducrocq et al. 2014). The synoptic situation was characterised by trough travelling from the southwestern Mediterranean that destabilised the warm and moist air present over the southern part of the Balearic Islands. In addition a low level convergence was present between Catalonia and the Balearic Islands. These meteorological conditions triggered $100 \mathrm{~mm}$ of rain in $24 \mathrm{~h}$ with wind gusts $\left(100 \mathrm{~km} \cdot \mathrm{h}^{-1}\right)$, hail and local flooding in the Balearic Islands.

Figure 3 shows DC and COV occurrence derived from MHS at 13:12 UTC on 12 October 2012 (Top), brightness temperatures from MHS (Middle) and reflectivity profiles from Rasta (Bottom). Reflectivity profiles cover the period between 12:50 and 13:20 UTC on the same day for flight 19 of the Falcon 20 aircraft. A convective area is visible over the Balearic Islands, characterised by brightness temperatures down to $200 \mathrm{~K}$ (Figure 3 Top). In the same region, an overshooting region of $170 \mathrm{~km}^{2}$ was detected from MHS, embedded within a deep convective region of approximately $240 \mathrm{~km}^{2}$ (15 pixels) over the southern coast of Majorca.

The cloud system sampled by the Falcon 20 aircraft was characterised by high reflectivities (Figure 3 (Bottom)) and again can be described in several segments. In the first segment, from 12:50 to 12:58 UTC (1)), clouds reached $10 \mathrm{~km}$ in height and showed low reflectivities ranging from -20 to $7 \mathrm{dBZ}$. Brightness temperatures from MHS (Middle) showed lower temperatures $(232-239 \mathrm{~K})$ for channel at $183.3 \pm 1 \mathrm{GHz}$ and higher temperatures $(253-261 \mathrm{~K})$ for channel at 


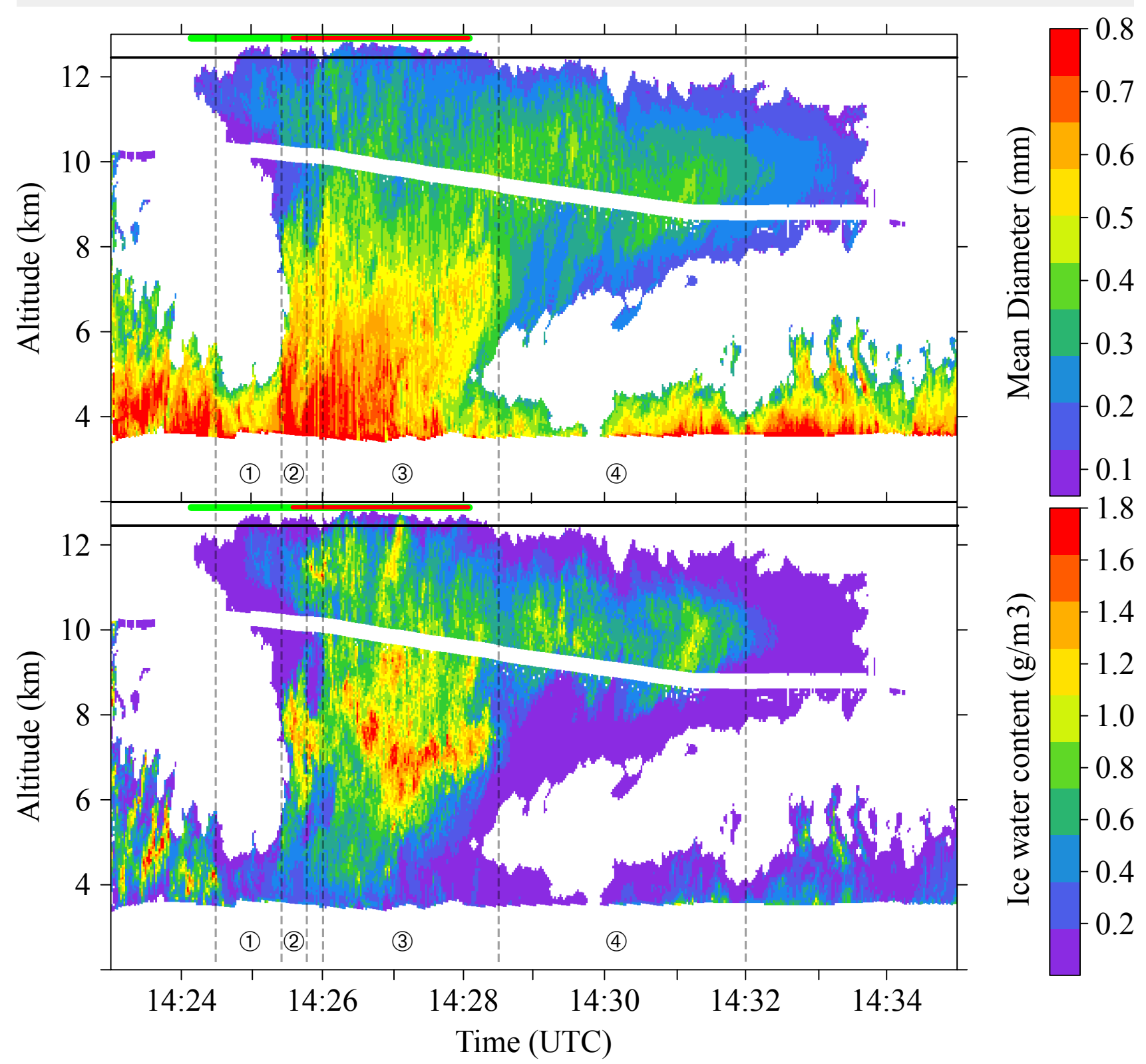

Figure 2. Case of 20 October 2012. Mean volume-weighted diameter of frozen hydrometeors (Top) and ice water content (Bottom) retrieved using Rasta radar. DC and COV are symbolised by green and red lines respectively and the tropopause height is displayed with a black line.

190.3 GHz. Consequently, neither COV nor DC were detected. In this cloud section, the mean diameter of the frozen hydrometeors ranged from approximately 0.4 to $0.6 \mathrm{~mm}$ between 3 and $6 \mathrm{~km}$, and from 0.1 to $0.4 \mathrm{~mm}$ at higher altitudes (Figure 4). The ice water content was low $\left(<0.5 \mathrm{~g} \cdot \mathrm{m}^{-3}\right)$.

From 12:58 to 13:01.5 UTC (2)), the reflectivity increased below 6-km altitude, but the top of the clouds remained unchanged. 


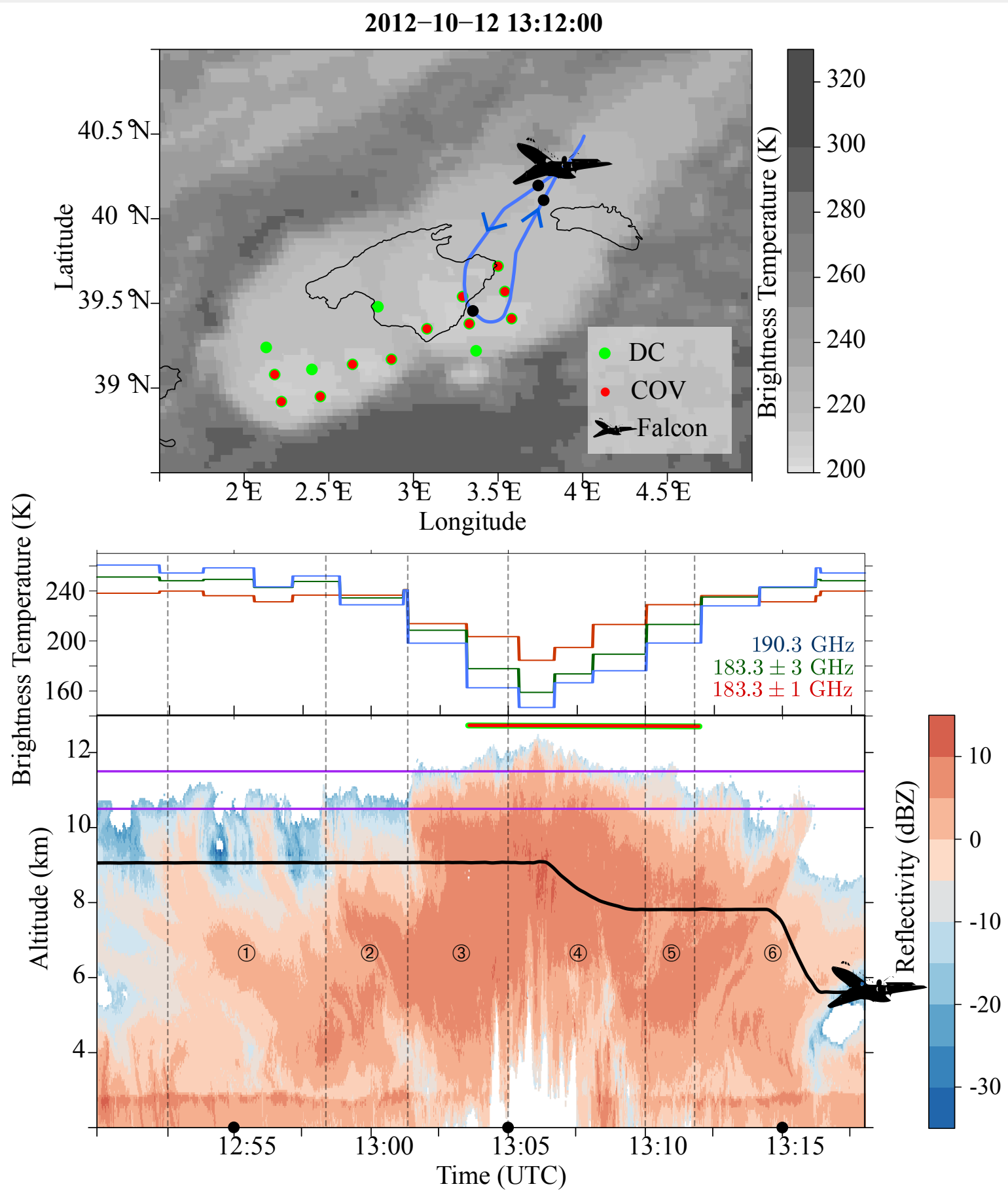

Figure 3. Case of 12 October 2012. (Top) Brightness temperatures from the MSG $10.8 \mu \mathrm{m}$ SEVIRI channel at 13:12 UTC are shown in grey levels, the track of the Falcon 20 is shown as a blue line, DC and COV are symbolised by green and red spots respectively. (Middle) Dark red (183.3 $\pm 1 \mathrm{GHz}$ ), dark green $(183.3 \pm 3 \mathrm{GHz})$ and dark blue $(190.3 \mathrm{GHz})$ lines show the MHS brightness temperatures from NOAA 18 satellite at 13:12 UTC for gridpoints that are the closest to the Rasta flight track. DC and COV are symbolised by green and red lines respectively. (Bottom) Reflectivity from Rasta radar is shown in colour, track of the Falcon 20 is shown as a black line, the tropopause height is displayed with purple lines. Black dashed lines highlight several segments of the cloud that are discussed in the text. Black points are displayed along flight track at 12:55, 13:05 and 13:15 UTC. 
From 13:01.5 to 13:05 UTC (3) the aircraft entered into a much more active section of the cloud system: the top of the clouds reached $11.5 \mathrm{~km}$ and the reflectivity at mid levels $(6-8 \mathrm{~km})$ surpassed $10 \mathrm{dBZ}$. Although lower brightness temperatures were found for channels further away from the centre frequency at $183.3 \mathrm{GHz}$, the DC criterion (Equation 1) was not fulfilled since the viewing angle was high $\left(>31^{\circ}\right)$ while the difference between channels $183.3 \pm 1$ and $183.3 \pm 3$ $\mathrm{GHz}$ was small $(\sim 5 \mathrm{~K})$. The mean diameter of frozen hydrometeors was high $(0.7 \mathrm{~mm})$ at low levels and moderate at mid and high levels $(0.4-0.5 \mathrm{~mm})$, while the ice water content was significant between 6 and $10 \mathrm{~km}\left(1.3\right.$ to $\left.1.8 \mathrm{~g} . \mathrm{m}^{-3}\right)$.

The following cloud segment (13:05 to 13:10 UTC (4)) appeared to be the most active part of the convective cloud system. The density of hydrometeors (ice, graupels and perhaps liquid water) was so considerable that sometimes, below $6 \mathrm{~km}$, there is complete radar signal extinction. The reflectivity was above $10 \mathrm{dBZ}$ from 7-8 $\mathrm{km}$ and approximately $5 \mathrm{dBZ}$ at higher altitudes. Moreover the cloud tops reached 12.3 km at 13:06.5 UTC. As expected, the lowest brightness temperatures $(<150 \mathrm{~K})$ were found for channels further away from the centre frequency at $183.3 \mathrm{GHz}$. Both COV and DC were detected in this region. Looking at the microphysics (Figure 4), the mean diameters were 0.6-0.8 above $7.5 \mathrm{~km}$ and the ice water content was from 1.4 to $2 \mathrm{~g} \cdot \mathrm{m}^{-3}$. In the most elevated part of the cloud, a column of high ice water content was found $\left(>2 \mathrm{~g} \cdot \mathrm{m}^{-3}\right)$.

From 13:10 to 13:12 UTC (5), the cloud top reached $11.5 \mathrm{~km}$ but reflectivity in high levels was much lower (-5 to $0 \mathrm{dBZ}$ ) than in previous segments whereas in lower levels, the reflectivity was approximately equal to $5 \mathrm{dBZ}$ (and slightly higher around $6 \mathrm{~km}$ ). Both DC and COV were detected in this region. It was a little surprising to find COV in the less active region of this cloud system. This can be attributed to the non-optimal colocation between the aircraft track and the MHS observation (they were at about $10 \mathrm{~km}$ apart as shown in Figure 3 (Top)). In this segment, the mean diameter of frozen hydrometeors was $0.5-0.6 \mathrm{~mm}$ for $3-7.5 \mathrm{~km}$ and from 0.5 to $0.15 \mathrm{~mm}$ at higher altitudes.

After 13:12 UTC (6), the aircraft moved into a less active part of the cloud system with lower cloud tops (8 km) and characterised by lower reflectivities (-5-5 dBZ). The order of brightness temperatures was progressively reverse compared 
to previous segments. The mean diameter of hydrometeors ranged from $0.6 \mathrm{~mm}$ at low levels to $0.2 \mathrm{~mm}$ at high levels, and ice water content was lower than $0.5 \mathrm{~g} \cdot \mathrm{m}^{-3}$.

Once again we checked the tropopause height to evaluate the COV assumption. The two atmospheric soundings from Majorca in Balearic Islands indicated a tropopause height of approximately $10.5 \mathrm{~km}$ and $11.5 \mathrm{~km}$ respectively at 00:00 UTC and 18:00 UTC. As a result, in this situation too, the COV criterion detected successfully the clouds of high altitude and high reflectivity.

\subsection{Discussion}

These two examples demonstrate the validity of the Hong et al. (2005) criterion for detecting convective overshoots in another region than the tropics. In addition, the retrieved microphysical properties of clouds allowed, for the first time, to characterize $\mathrm{COV}$ in terms of diameter and content of frozen hydrometeors. We found that COV is associated with a heavy loading of frozen hydrometeors, above $1.5 \mathrm{~g} . \mathrm{m}^{-3}$ in the middle-to-upper troposphere and up to $0.3 \mathrm{~g} . \mathrm{m}^{-3}$ above the tropopause. For the 20 October case, the intrusion into the stratosphere was observed by Rasta during approximately 3.5 minutes. Therefore, given a Falcon 20 flight speed of $800 \mathrm{~km} \cdot \mathrm{h}^{-1}$, the COV area diameter is estimated to be $50 \mathrm{~km}$. This matches well with the area deduced using MHS. Regarding the 12 October case, as the aircraft was forced to turn around as it reached the most intense part of the cloud (13:05.5), it is not possible to estimate the COV area diameter using Rasta observations.

Within regions where COV was observed, the Rasta observations also revealed several fine-scale elevated towers reaching $12-\mathrm{km}$ altitude with reflectivity up to $5 \mathrm{dBZ}$, hydrometeor content of $1.5 \mathrm{~g} \cdot \mathrm{m}^{-3}$ (corresponding to a mixing ratio of $5 \mathrm{~g} . \mathrm{kg}^{-1}$ given an air density of $0.3 \mathrm{~g} . \mathrm{m}^{-3}$ ) and diameters up to $0.4 \mathrm{~mm}$. Such towers were observed for about $30 \mathrm{~s}$, or along a distance of approximately $6 \mathrm{~km}$. They corresponded well to the overshooting tops detected in the infrared imagery reported in the literature. The latter appeared as small clusters $(<15 \mathrm{~km}$ in diameter $)$ of very low brightness 


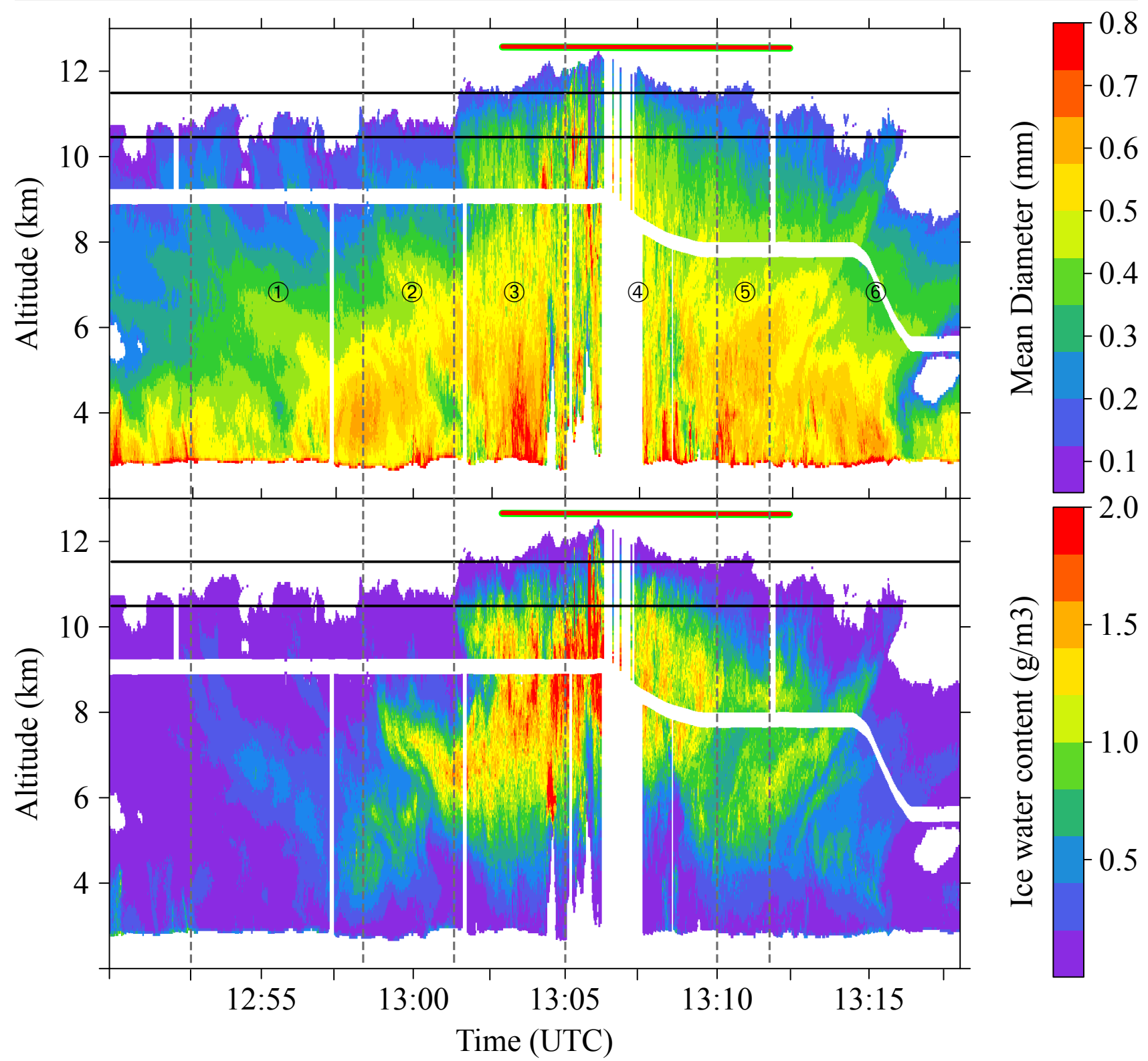

Figure 4. Case of 12 October 2012. Mean volume-weighted diameter of frozen hydrometeors (Top) and ice water content (Bottom) retrieved using Rasta radar. DC and COV are symbolised by green and red lines respectively and the tropopause height is displayed with a black line.

temperatures (Bedka 2011). They are explained as vertical updrafts intruding the stratosphere and cooling at a rate of 7-

$9 \mathrm{~K} . \mathrm{km}^{-1}$. This results in a significant contrast between the region of overshooting tops and the surrounding anvil clouds.

Such updrafts are of great importance for troposphere-stratosphere exchange. To the best of the authors knowledge, both HyMeX cases shown here are the very first observations of the vertical structure of updrafts overshooting the tropopause reported in the Mediterranean. 


\section{Severe convection during the HyMeX SOP-1}

The HyMeX SOP-1 took place from 5 September to 6 November 2012. In this section, we study the temporal and spatial variability of DC and COV occurrences during the whole campaign in the Mediterranean region $\left(10^{\circ} \mathrm{W}-35^{\circ} \mathrm{E}\right.$ and $32^{\circ} \mathrm{N}-$ $48^{\circ} \mathrm{N}$ ). To this end, we compute DC and COV occurrence for a $0.2^{\circ}$ grid and we normalise these occurrences using the total number of satellite observations. In the following, the results are given as a percentage of observations.

\subsection{Temporal variability}

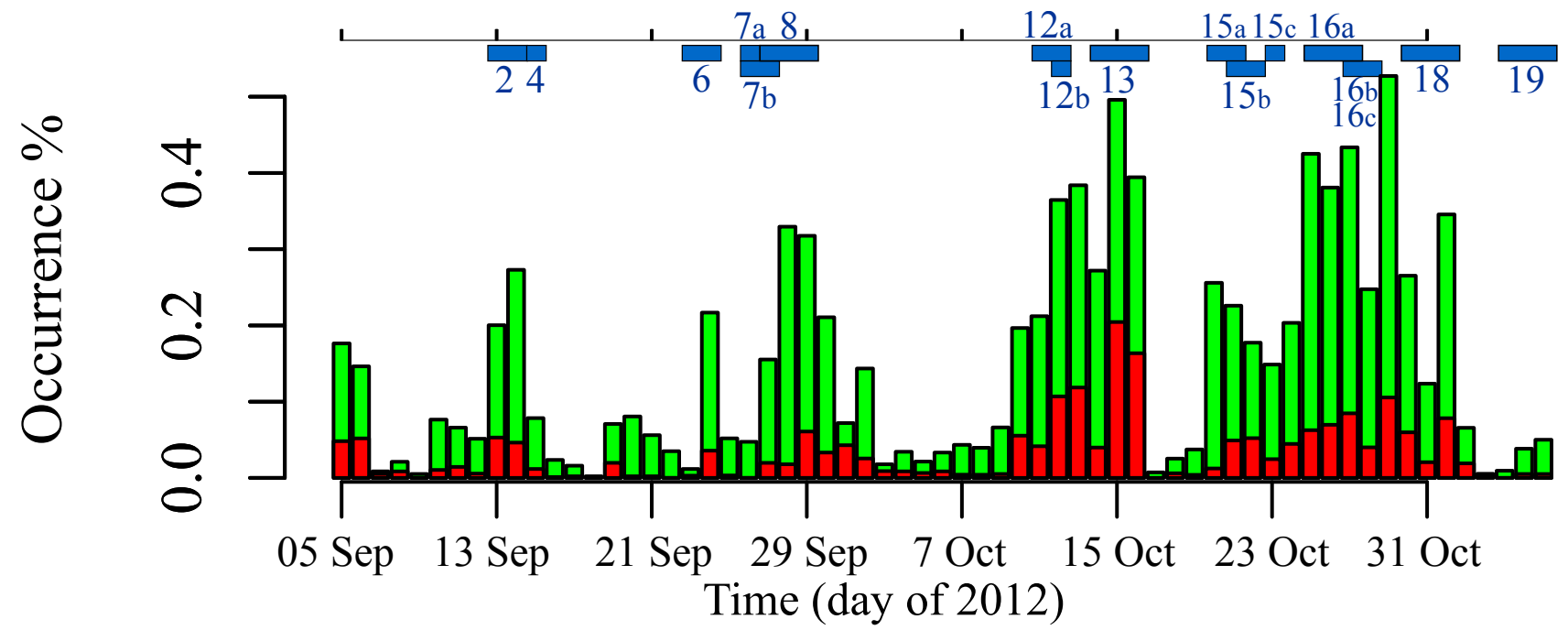

Figure 5. Occurrences of DC (green) and COV (red) in \% during the HyMeX SOP-1. Note the occurrences are computed for the whole Mediterranean basin (not only in the western Mediterranean where the SOP-1 took place). Intensive observation periods (IOPs) for heavy precipitation events, flashflood events and strong wind events are shown as blue boxes and labels.

Four episodes of strong convective (DC and COV) activity took place during the HyMeX SOP-1 (Figure 5): 1314 September, 27-30 September, 10-16 October and 20 October-3 November. These episodes cover all the IOPs (Intense Observation Periods) targeted on heavy precipitation, flash-floods and strong wind events (Ducrocq et al. 2014). Less than $40 \%$ of total DC events and less than $35 \%$ of total COV events occurred during the first part of the HyMeX SOP-1 (5 September-9 October). Over the northwestern Mediterranean, supercells with heavy hail and wind gusts were reported in Catalonia and Majorca on 12-13 September. In another event, several mesoscale convective systems associated with a cut-off low resulted in a flash-flood and a tornado that caused 13 casualties and 120 millions of euros of damage in 
Spain between 27-29 September. The second part of the HyMeX SOP-1 was more active. The 10-16 October episode is characterised by heavy convective activity during $0.25 \%$ of the time on average, with COV occurrence accounting for a third of all deep convection cases. A second episode (20 October-3 November) had the highest activity in terms of convective events $(\sim 0.3 \%$ of the time on average, with a peak of $0.5 \%$ on 29 October) but showed fewer strong and elevated convective towers $(0.05 \%)$. During the last two episodes, severe weather events such as heavy rainfall, flooding, a tornado and high waves were reported over Spain, France and Italy as well as 6 casualties.

The convective activity can be related to the Atlantic weather regimes that occurred during the HyMeX SOP-1 and described by Ducrocq et al. (2014). Specifically, episodes with low convective activity were associated with an Atlantic ridge weather regime (5-23 September) and to a positive phase of North Atlantic Oscillation (NAO) (at the beginning of October). Conversely, the episodes of strong convective activity were associated with negative NAO phases (23-30 September and 27 October-5 November) or a blocking phase (16-26 October). These two weather regimes are usually related to unstable weather in the Mediterranean (Ducrocq et al. 2014). For instance Chaboureau and Claud (2006) showed that cloud systems were found more frequently during the negative NAO phase. Overall these results show a relationship between occurrence of DC and COV and large-scale weather systems and are consistent with Funatsu et al. (2008) who showed that an upper-level trough was present in about half of DC events in the autumn.

In order to compare the observed patterns of convective activity during the HyMeX SOP-1 with previous years, we used the same time frame (i.e., 5 September to 6 November) from 2002 to 2013 to compute the 12-year average of DC and COV occurrence (Figure 6). Overall the frequency of DC events swung around $0.2 \% \pm 0.1 \%$ while the occurrence of COV events decreased with time from approximately 0.05 to $0.025 \%$. The inter-annual variability of DC and COV was strong, as shown by the interquartile range (shaded area). This was also true for the HyMeX SOP-1 as shown by the difference in their occurrence against the 2002-2013 period. During the HyMeX SOP-1, DC and COV activity was not notably different from the 2002-2013 period except for the episode of 11-16 October 2012 which was especially noticeable with COV occurrence 2 to 4 times above average values. During this episode, two exceptionally large convective systems 

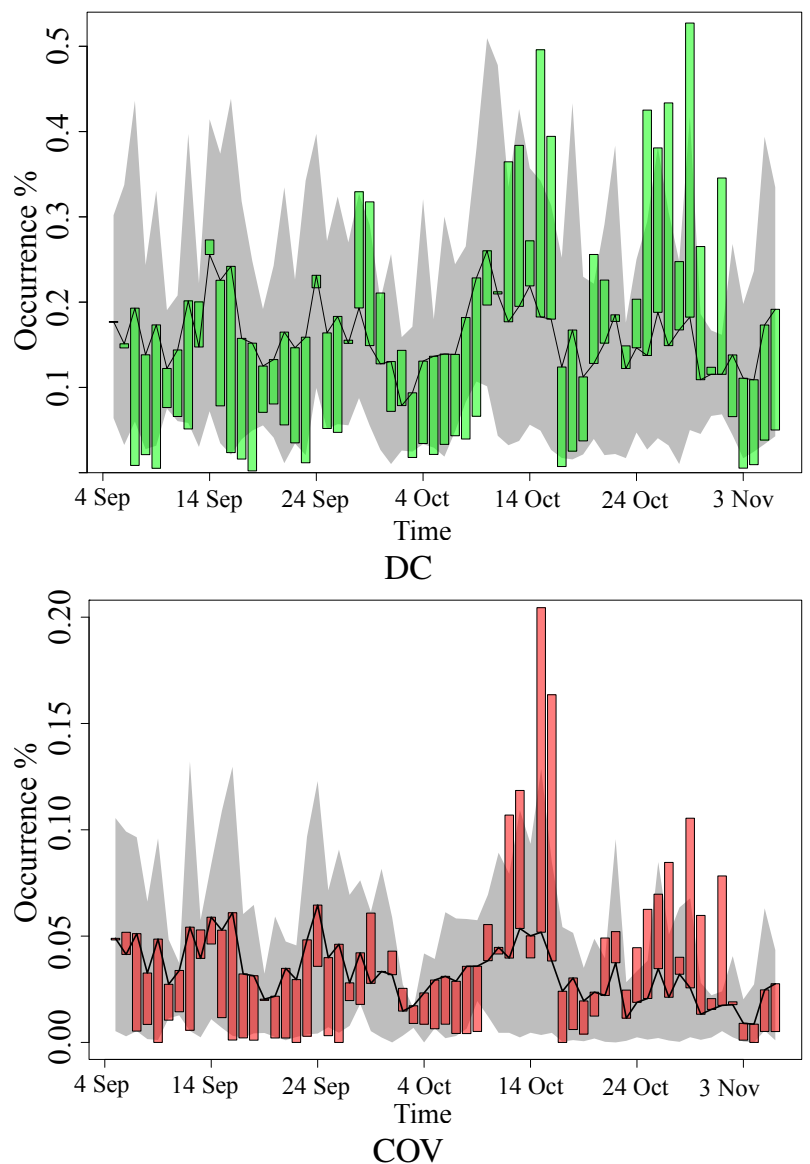

Figure 6. Black line indicates average DC (green, top) and COV (red, bottom) occurrence during the 2002-2013 period. Boxes indicate the difference between the HyMeX SOP-1 and the 2002-2013 period. Shaded grey shows the interquartile range of DC/COV occurrences during the $2002-2013$ period.

2012-10-15 19:40:00

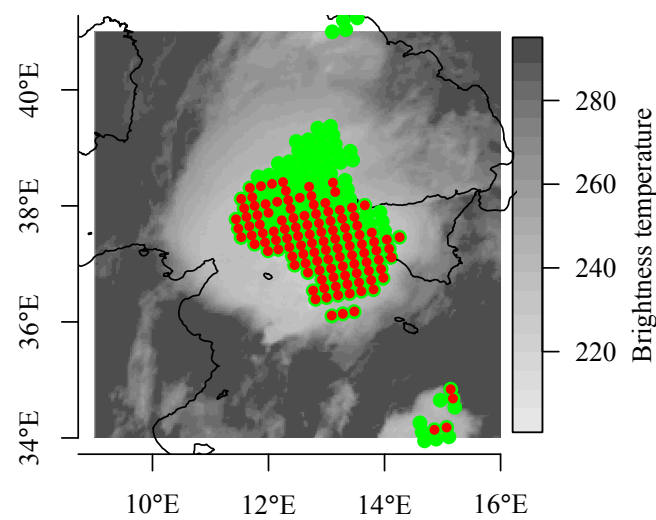

2012-10-16 00:45:00

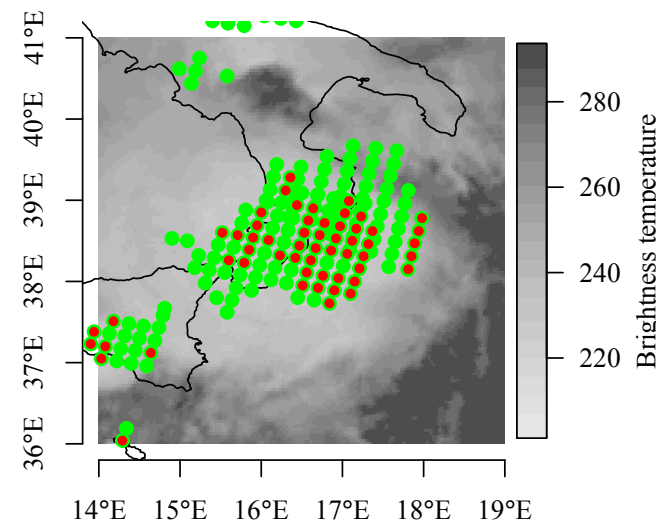

2012-10-16 12:35:00

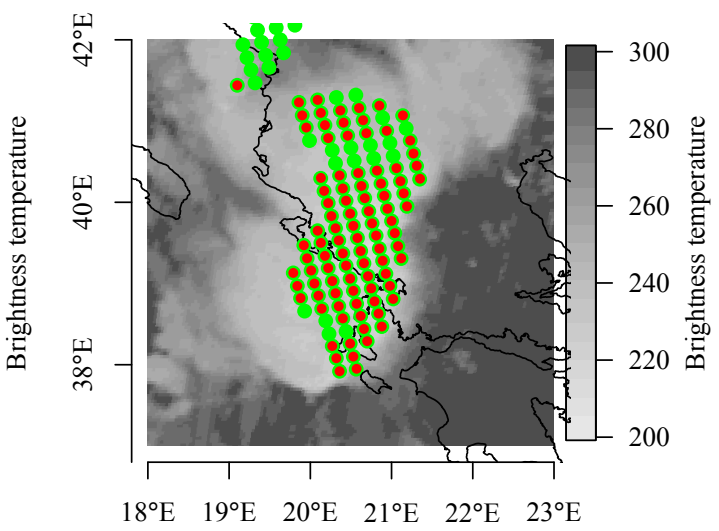

Figure 7. Case of 15-16 October 2012. Brightness temperature from MSG $10.8 \mu \mathrm{m}$ SEVIRI channel is shown in grey levels and DC and COV are symbolised by green and red spots.

with diameters higher than $300 \mathrm{~km}$ travelled from Tunisia to Greece and numerous convective structures developed in the Ionian Sea. The 15-16 October event is presented in Figure 7. The large scale situation of the 15-16 October event was quite 
common with a cold front from Algeria to Corsica that moved slowly eastward. Ahead of this front, a mesoscale cyclonic system developed a considerable COV region with a diameter of $200 \mathrm{~km}$ making this event particularly remarkable. Unfortunately no flight was possible in this area at that time. During these two days, heavy rainfall along the eastern coast of the Adriatic Sea were reported as well as severe winds between Tunisia and Sicily, large hail in Sicily and a tornado along the western coast of Greece.

Figure 6 also reveals that from 25 October to 2 November, convective activity (DC) was twice as high as the 12-year daily average value. This convective activity was related to a low pressure system that travelled slowly from western Spain to eastern Greece. This low pressure triggered frontal activity that in turn favoured convective activity ahead of the front. During this period, meteorological services reported numerous severe weather events in the Mediterranean: heavy rain and severe winds along western Italy, south-eastern France and the eastern Adriatic coast, tornadoes in northeastern Spain, Corsica, central Italy, Sicily, Malta, Croatia and western Greece.

\subsection{Spatial variability}

The spatial distribution of DC and COV is shown in Figure 8. Areas of high convective activity were mainly located over the sea and the north-western coasts of the Mediterranean basin. In particular, Albanian and Greek western coasts showed DC occurrence as high as 2.5-3\% and Turkey, Sicily, Corsica, Sardinia, the Balearic Islands and the western and southern coasts of France, as well as the Sea of Marmara showed DC occurrences from 1.5 to $2 \%$. Regarding COV, the western Sicilian coast was strongly affected by these events during the HyMeX SOP-1 (frequency up to $1.5 \%$ ). Other areas with significant number of COV were the southern coast of Italy (1\%), the western coast of Albania and Greece (up to $2 \%$ ), the Gulf of Lyon $(>1 \%)$, the Tyrrhenian Sea $(>2 \%)$, the Ionian Sea $(>1 \%)$ and the Straits of Sicily $(>2 \%)$. Only a few studies provide information about the occurrence of convective activity over the sea in the Mediterranean region: Funatsu et al. (2009) showed a similar pattern to our results, with DC occurrence mainly over the sea, with the exception of the Spanish and Tunisian coasts where DC is more frequent in Funatsu et al. (2009). Similarly, Melani et al. (2013) 


\section{Deep Convection}

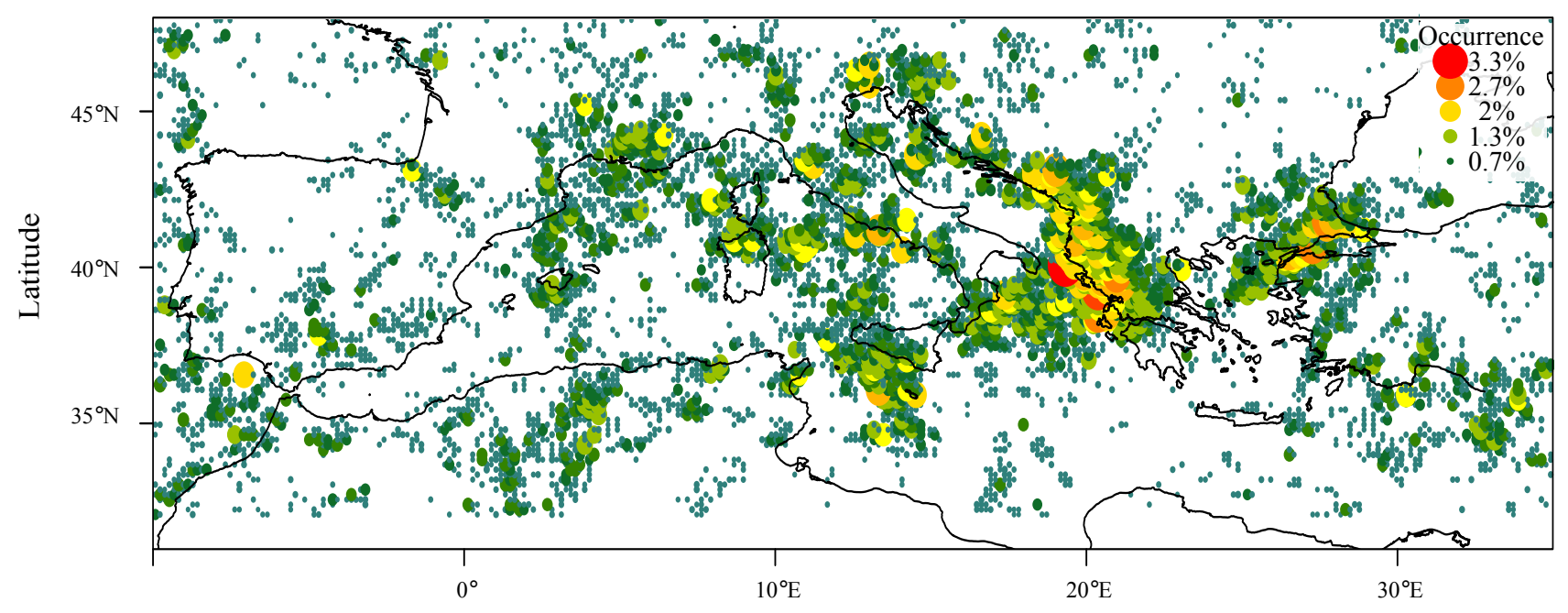

Convective Overshooting

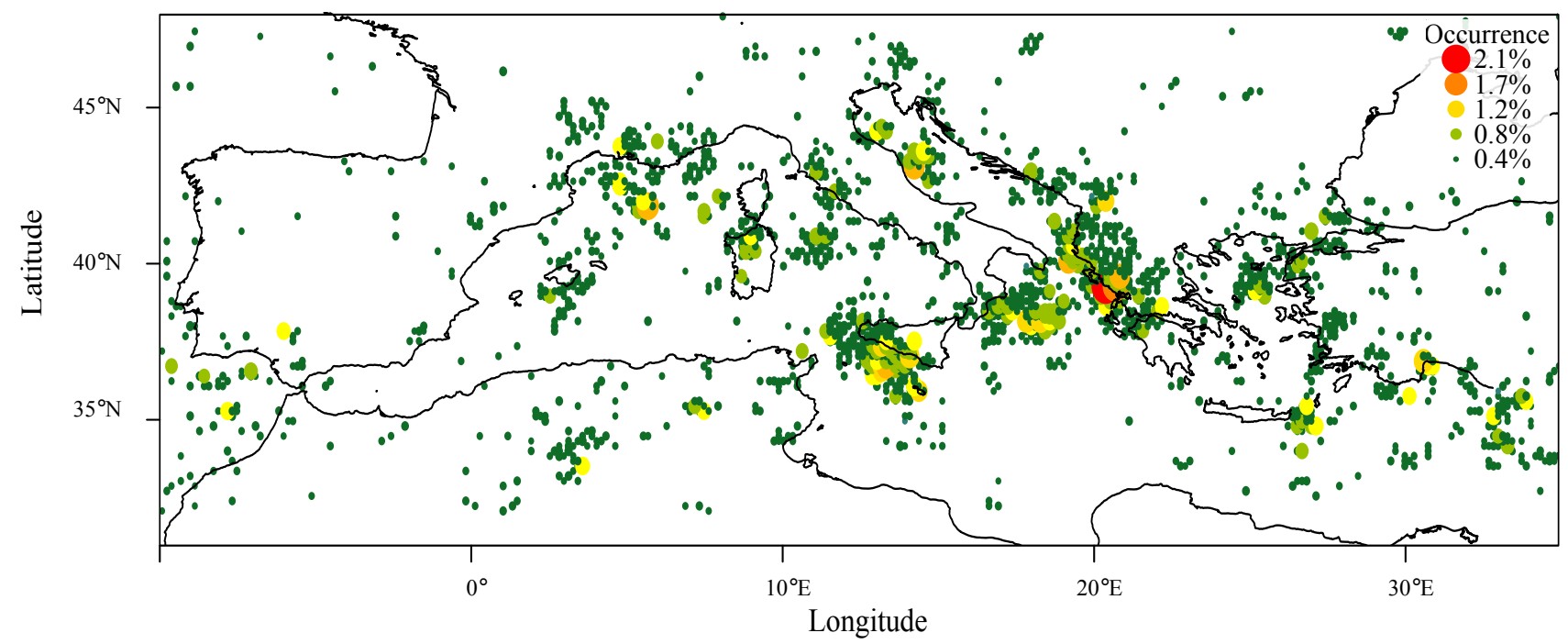

Figure 8. Occurrences of DC (top) and COV (bottom) during the HyMeX SOP-1. The occurrence are expressed as specific values.

showed that long lasting deep convective systems occur in regions where we identified high occurrence of DC, that is southeastern Sicily, the Balearic Islands and the Ionian and Tyrrhenian seas, while Bedka (2011) detected overshooting tops preferentially in the western Mediterranean sea and northwestern Africa using infrared imagery.

The interannual variability in the convective activity in autumn is high as noted by Funatsu et al. (2009); Bedka (2011) and Melani et al. (2013). Figure 9 shows the difference in DC and COV between the HyMeX SOP-1 and the whole 2002-2013 period. On the one hand DC and COV events are slightly below average during the HyMeX SOP-1 for the 


\section{Deep Convection}

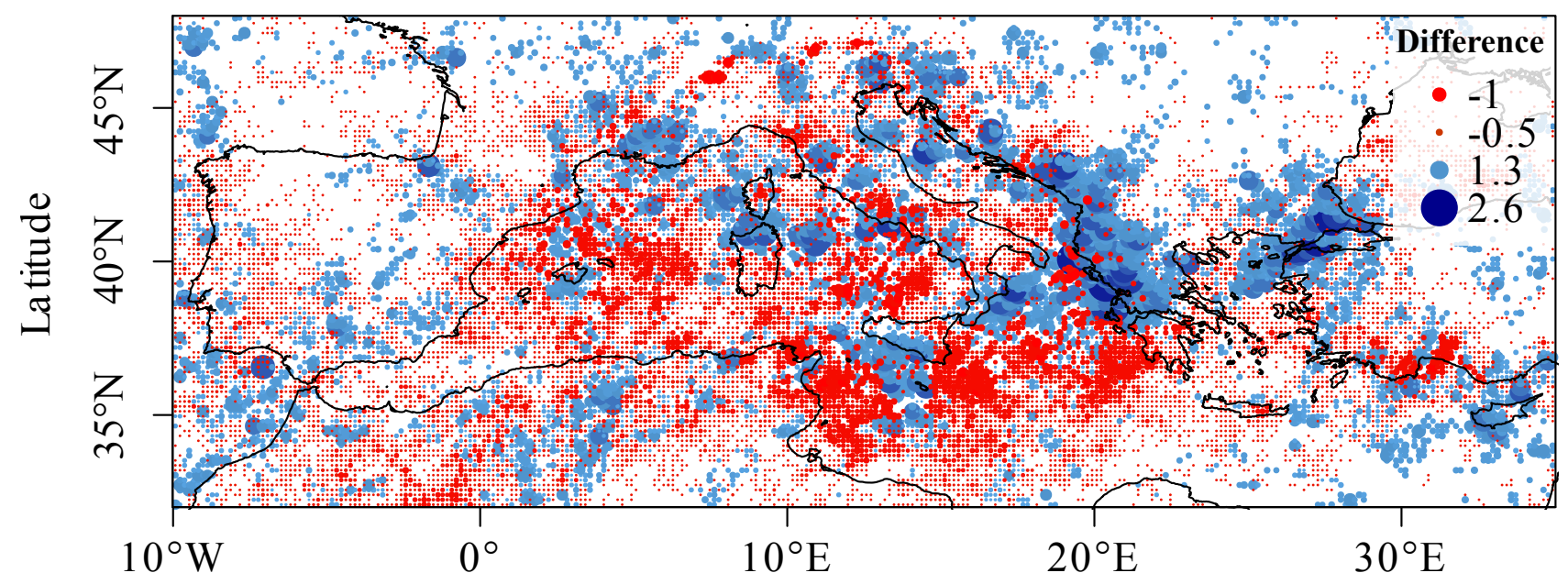

Convective Overshooting

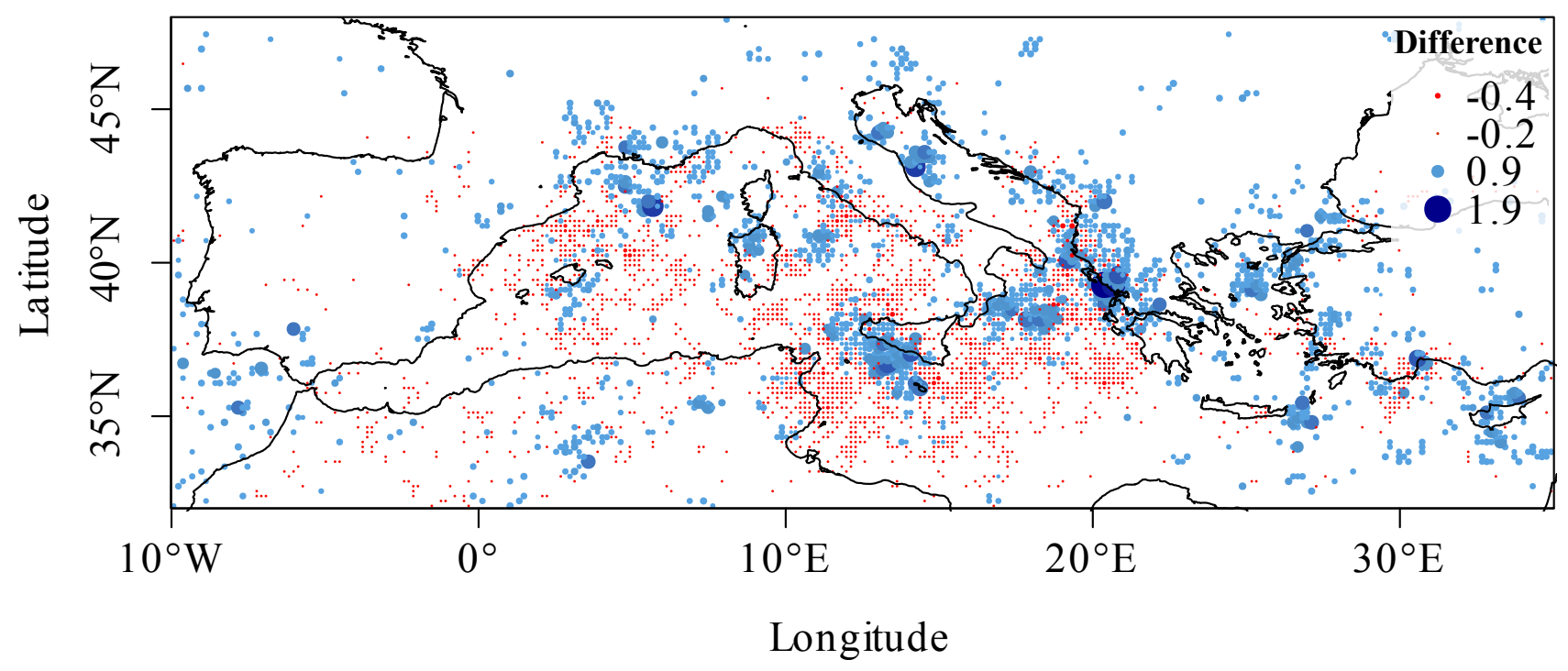

Figure 9. Difference of occurrence of DC and COV between the HyMeX SOP-1 and 2002-2013 period. The difference are expressed as specific values.

south-western part of the Mediterranean region (down to -1\%). On the other hand, DC occurrence is above the mean for the western Albanian and Greek coasts ( 1.5-2.5\%), while COV occurrence is above the mean for the western Greek and Sicilian coasts as well as southern Italy $(\sim 1-2 \%)$.

Both Figures 8 and 9 reveal the existence of a DC "alley" from Tunisia to Greece during HyMeX SOP-1. This DC "alley" is also observed on average for the whole 2002-2013 period (not shown). A number of mesoscale convective systems occurred during the HyMeX SOP-1 in the Adriatic Sea and the Ionian Sea as revealed by the MSG imagery (not 
shown). They likely explain the high number of DC and COV occurrences in this region. As underlined in Melani et al. (2013), who also observed strong convective activity over these areas based on a totally independent approach, reasons that could explain preferential areas for DC and $\mathrm{COV}$ occurrence remain unclear, but two factors play a significant role: first, in the Mediterranean region, coastal regions often present steep orography that triggers convergence and vertical air motion (Rotunno and Ferretti 2003; Bousquet and Smull 2006). Second, positive anomalies of the sea surface temperature might also affect the distribution of convective events (Funatsu et al. 2009). It is also interesting to note that the track of medicanes (Mediterranean tropical-like cyclones) often matches the DC "alley" (Claud et al. 2010; Chaboureau et al. 2012b; Tous and Romero 2013; Miglietta et al. 2013). Our results also show that the western coasts of land are mostly affected by DC and COV, very likely because these convective events are often associated with frontal systems that come from the west i.e., the Atlantic region (Kotroni et al. 1999; Funatsu et al. 2008).

\section{Comparison of DC and COV occurrence between observations and the Meso-NH model}

One of the main objectives of the HyMeX campaign is to improve the forecast of heavy precipitation events. To this end, about 30 atmospheric research and operational models were run during the whole SOP-1 (see Table ES4 of Ducrocq et al. 2014). Among them, 11 convection-permitting models provided deterministic forecasts over domains covering the western Mediterranean with grid spacing ranging from 1.5 to $3 \mathrm{~km}$ (see Figure 5 of Ducrocq et al. 2014). In this section, we evaluate the capacity of the Meso-NH model to reproduce DC and COV occurrence during the HyMeX SOP-1. As yet, no attempt has been made to calculate any categorical score for assessing the capability of Meso-NH to forecast DC and $\mathrm{COV}$ at the right location and at the right time.

\subsection{Meso-NH specification}

During the HyMeX SOP-1, the Meso-NH model (Lafore et al. 1998) was run daily for $48 \mathrm{~h}$ from 29 August to 6 November 2012. The initial and boundary conditions were provided by European Center for Medium-range Weather Forecasts (ECMWF) analysis and forecasts issued at 00:00 UTC each day. In the case of heavy precipitation events over 
the western Mediterranean, the model was run using the two-way interactive grid-nesting method (Stein et al. 2000) with two nested grids, a horizontal grid mesh of 15 and $2.5 \mathrm{~km}$ and a vertical grid with 62 levels. Otherwise, the model was run with the coarser grid only. The model includes parameterisations for radiation (Mlawer et al. 1997), turbulence (Cuxart et al. 2000), subgrid shallow convection (Pergaud et al. 2009), mixed-phase microphysics (Pinty and Jabouille 1998), subgrid cloud cover and condensate content (Chaboureau and Bechtold 2005) and surface exchanges (Masson et al. 2013). The convection scheme of Bechtold et al. (2001), was activated for the 15-km grid, while convection was assumed to be explicitly resolved for the $2.5-\mathrm{km}$ grid ( 648 by 480 grid points, see the domain in Figure 8 ). From the model outputs available every 3 hours, brightness temperatures were computed using the radiative transfer code RTTOV (Radiative Transfer for Tiros Operational Vertical Sounder) version 11 (Saunders et al. 2005). The scattering properties of frozen hydrometeors were those calculated by Geer and Baordo (2014) for dendrite snowflakes using the discrete dipole approximation, while precomputed Mie tables were used for other hydrometeors. The simulation of brightness temperatures from the model outputs allowed a direct comparison with passive microwave observations. Such a comparison, the so-called model-to-satellite approach has already been performed successfully at various wavelengths and has shown the overall performance of the Meso-NH model to correctly predict cloud and rain fields (Chaboureau et al. 2008; Söhne et al. 2008; Clark and Chaboureau 2010; Chaboureau et al. 2012a,b, amongst others). In this study, the comparison is restricted to the inner model $(2.5-\mathrm{km}$ grid) where the convection is resolved. For each mesh point of the model, the MHS synthetic brightness temperatures are computed and the DC and COV criteria are applied. The normalised occurrence of DC and COV is then computed for a $0.2^{\circ}$ grid to be compared with those derived from MHS observations.

\subsection{Results}

As observed, DC was mainly forecasted over the Mediterranean sea and the surrounding land, with occurrences ranging mainly from 0.7 to $1.3 \%$ (Figure 8 ). Moreover, DC was present for almost every grid point in the simulations, while absent in some regions in the observations. This non-ubiquitous distribution in the observations may be attributed to a 


\section{Deep Convection}
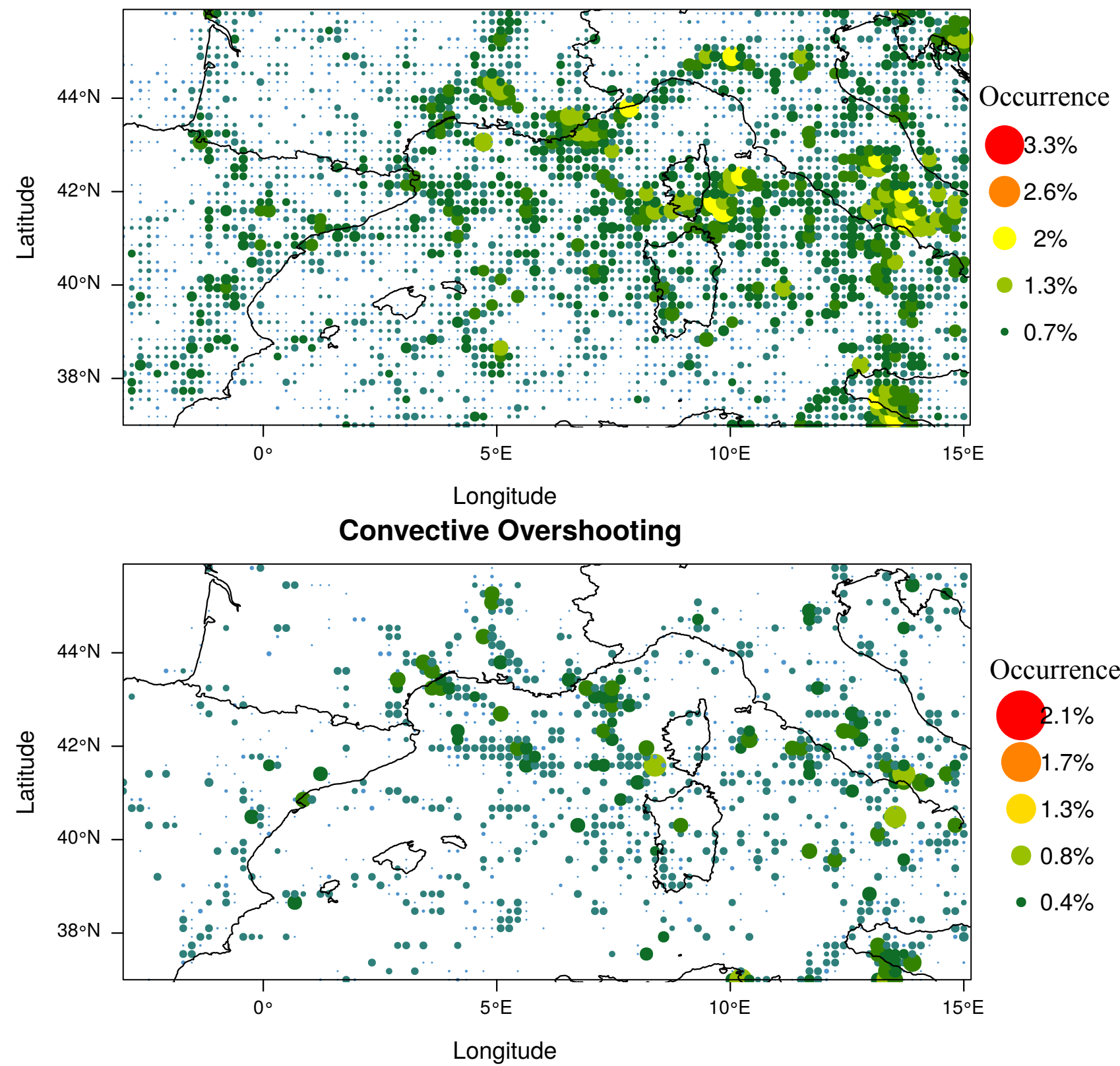

Figure 10. Occurrence of DC (top) and COV (bottom) during the HyMeX SOP-1 for the Meso-NH model. The occurrences are expressed as specific values.

sampling issue. Another explanation could be a lack of organised mesoscale convective systems in the forecasts. Indeed, more isolated convective storms are likely to result in DC occurrence which are scattered more widely over the domain.

However, the model shows a few areas with occurrences larger than $1.3 \%$ : southwestern Sicily, eastern Corsica, in the vicinity of Roma, northwestern Italy and southeastern France. In particular, DC was forecasted over Sicily at the right 
location and with the right occurrence. Other hot spots in the forecasts were slightly offset compared to the observations (e.g., DC was observed in western Corsica, but forecasted in eastern Corsica) and with lower occurrence (Figure 8). Again, this could be explained by the sampling issue and some model deficiencies as detailed below. The distribution of forecasted COV occurrence mimics its DC counterpart, but with a reduced number to those observed.

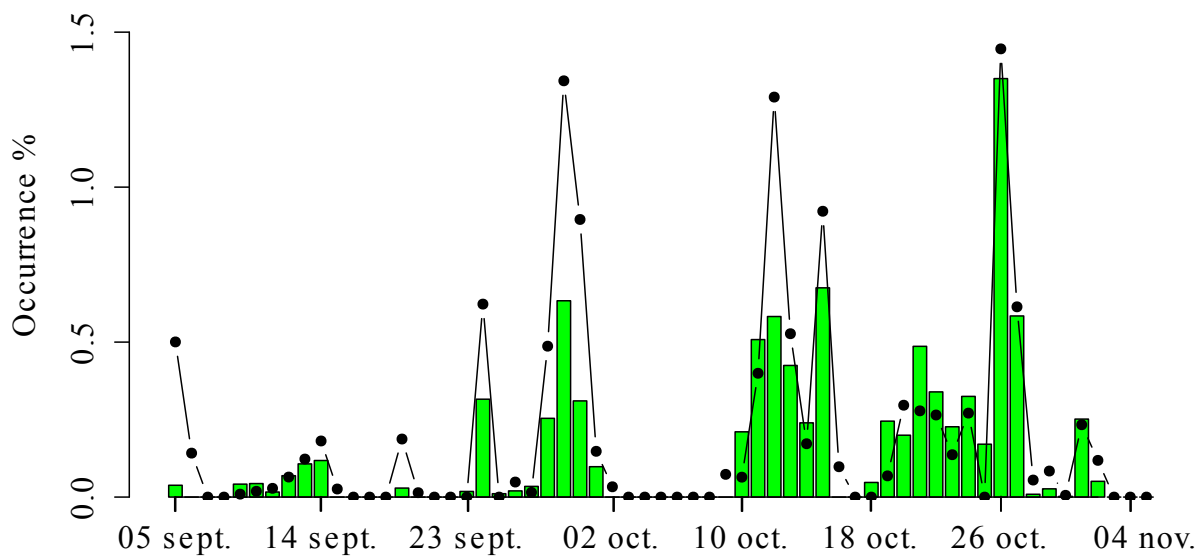

(a)

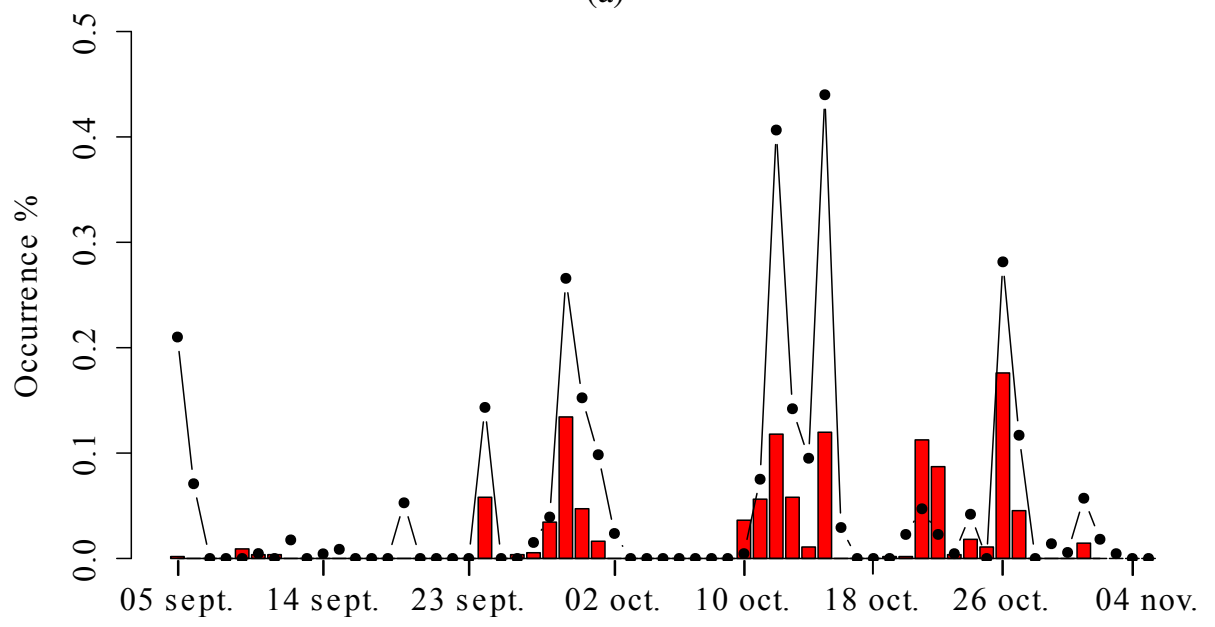

(b)

Figure 11. DC occurrence for the Meso-NH model (green) and observations (black dots) (Top). COV occurrence (red) and observations (black dots) (Bottom). Occurrences are computed for the $2.5-\mathrm{km}$ grid of the Meso-NH model $\left(3^{\circ} \mathrm{W}-15^{\circ} \mathrm{E}\right.$ and $\left.37^{\circ} \mathrm{N}-46^{\circ} \mathrm{N}\right)$.

The comparison was further pursued by examining the time evolution (Figure 11). Periods of high DC activity (1316 September, 27-31 September, 10-15 October and 19 October to 1 November) were well forecasted. As a result, the correlation coefficient between forecasts and observation was 0.86 . Such a high value is likely due to the nature of convective systems that yield a DC signature. Indeed, as noted in the previous section, most of them were associated 
with synoptic-scale troughs that are usually well described in modern operational analysis (Ducrocq et al. 2014; Ferretti et al. 2014). As a consequence, convection was triggered at the right time in the daily forecasts of the convection-permitting model. Yet, the average DC occurrence in the forecasts was two times lower than in the observations. The time evolution of COV was less accurately reproduced than for DC and the correlation coefficient was 0.74 . Overall, the occurrence of $\mathrm{COV}$ in the forecasts was five times lower than in the observations.

Several factors could explain the discrepancies between observations and forecasts, in particular those seen in the spatial distribution. The first factor is the sampling issue. On the one hand, the sensitivity of DC and COV to the time of the day was examined in the three-hourly forecasts. It results that DC and COV are both very intermittent events. One the other hand, the three polar-orbiting satellites fly over the Mediterranean up to 6 times a day, so less regularly and frequently than the 3-hourly model outputs. However no systematic variation of DC and COV with time was found in the forecasts (not shown). This suggests that the observations should not present any systematic bias with respect to the time of the day.

A second factor explaining the discrepancy could be the frozen hydrometeors produced by the model. They have certainly not always been forecasted at the right time and/or the right place. Forecasting localised intermittent events such as thunderstorms is a big issue that is, however, outside of scope of the present study. Beyond this predictability issue, it is not clear whether the frozen hydrometeors are forecasted with correct amounts or not. In a recent model intercomparison study focusing on a intense tropical mesoscale convective system, Varble et al. (2014) found a high positive bias on simulated convective areas for all the evaluated models, including Meso-NH. This bias was the result of overly intense updrafts partly due to over-strong convective dynamics and the freezing of liquid condensate in parameterised microphysics. Conversely, we show here that DC and COV were underestimated by the model, highlighting the difficulty in forecasting severe convection accurately and universally.

A final factor explaining the discrepancy is the great sensitivity of the simulated microwave signal to the assumptions made in the radiative transfer model (Saunders et al. 2005). In particular, Geer and Baordo (2014) found that the simulated signal varies greatly with the choice of snow particle shape and size distribution. We too found a similar sensitivity 
here (not shown). A more detailed case study will allow us to disentangle the uncertainties due to the dynamics and the microphysics from those associated with the radiative properties of frozen hydrometeors.

\section{Conclusion}

In this paper, we used a method proposed by Hong et al. (2005) to detect Deep Convection (DC) and Convective Overshooting (COV) during the HyMeX SOP-1, based on passive microwave measurements from MHS (Microwave Humidity Sounder). In the first part of this study, we took advantage of the observations gathered during the SOP-1 to evaluate the COV method (the evaluation of DC has been achieved previously). In particular, we validated the method for two convective events sampled conjointly by MHS and the airborne Rasta radar. As expected, COV was detected for these two events where convective clouds rose beyond the tropopause. Our analyses showed that COV were associated with high reflectivity (up to $15 \mathrm{dBZ}$ ) and high ice water content (up to $2 \mathrm{~g}^{3}$ ) in mid and high levels of the troposphere.

In a second part, we studied the spatial and temporal variability of DC and COV during the HyMeX SOP-1. A risk for every field campaign is that the observation period does not present the expected meteorological conditions, but we showed that while the beginning of the campaign was dryer than one would have expected, the second part was impacted by a significant number of heavy precipitation events. The most active episodes of the HyMeX SOP-1 were found in the 10-16 October and the 20 October-2 November periods. The whole northern part of the Mediterranean basin was impacted by severe convection but the most affected regions were the western part of the Greek coast, the Sea of Marmara and the Sicilian Island where up to two cumulated days of DC occurred during the HyMeX SOP-1. The comparison of the HyMeX SOP-1 with the 2002-2013 period indicated that the SOP-1 falls mostly within the interquartile range, except for some instances in the second half of the SOP period. The southern part of Mediterranean basin was less impacted than average while the northern part (and in particular the Greek coast) was more impacted. Moreover, less DC and COV than average occurred during the period from 5 September to 11 October, while during the second part of the SOP-1 (11 October6 November), convective activity was higher than average. The temporal distribution of convective events appeared to be 
related to the Atlantic weather regimes. In particular, NAO- and blocking conditions were associated, for the SOP-1, with strong convective activity.

The last part of this paper was devoted to the evaluation of severe convection forecasts in the Meso-NH model through a model to satellite approach. Overall, this evaluation revealed that the forecast of DC and COV is satisfactory since their locations are rather similar to the observations, and with fairly high temporal correlation coefficient values ( 0.86 for DC and 0.74 for $\mathrm{COV}$ ). Yet, the occurrences computed from the convection-permitting model tend to be lower than in the observations. These results underline the efforts needed for a better characterisation of the model uncertainties associated with the dynamics, microphysics and radiative properties of frozen hydrometeors.

In summary, this paper showed that the DC and COV criteria developed by Hong et al. (2005) can be applied in the Mediterranean region during the autumn. It also provided very unique observations of the vertical structure of two severe thunderstorms that could help to gain a better understanding of their underlying dynamics. Moreover, it revealed periods and regions that were the most favourable to DC and COV during the HyMeX SOP-1. An important aspect is that we detected a significant amount of DC and COV over sea where very few measurements are available. Thus there is a clear need to find innovative solutions (e.g., meteorological radar on-board ships, microwave radiometers on-board geostationary satellites) in addition to the existing ones (MHS on-board heliosynchronous platforms, SEVIRI on-board MSG) to monitor severe convection over sea.

As this study highlights the occurrences of COV events in the Mediterranean region, the question of possible troposphere-stratosphere exchanges associated with these events must be addressed, as they can significantly modify stratospheric air composition. For instance, in one of the few in-situ observations of troposphere-stratosphere exchange related to deep convection at mid-latitudes (see also Poulida et al. 1996; Hegglin et al. 2004; Homeyer et al. 2014), Fischer et al. (2003) showed that for an event in the Mediterranean, that up to $50 \%$ of lower stratospheric air originates from boundary layer air in such convective events. 
Space-borne passive microwave sounders for water vapour observation have provided data since 1999 with several different radiometers, among them MHS, AMSU-B and ATMS (Advanced Technology Microwave Sounder) are nearly equivalent instruments. In this paper, we only used the former, but we plan to use the other two to provide a climatological analysis of DC and COV over the whole period. The same analysis could also be extended to other mid-latitude regions. In the future we also plan to use the huge number of measurements acquired during the HyMeX campaign for case studies that will help to characterise small scale properties of DC and COV events better. In particular, 3D reflectivity and microphysical characteristics derived from the radar network measurements appear to be promising for a better understanding of COV (see recent works of Homeyer and Kumjian (2014)). Finally, the ability of other models that ran during the HyMeX SOP-1 to forecast DC and COV in the Mediterranean basin will be evaluated.

\section{Acknowledgement}

This study was sponsored by the Direction Générale de l'Armement (PRECIP-CLOUD project), Earth2Observe project (funding from the European Union's Framework Programme under grant agreement number 603608), the ANR-14-CE010014 MUSIC project, and the Centre National d'Études Spatiales (CNES). MHS data was obtained through the French Mixed Service Unit project ICARE/climserv. Rasta data were obtained from the HyMeX program, sponsored by Grants MISTRALS/HyMeX and ANR-11-BS56-0005 IODA-MED project. The authors thank the anonymous reviewers for their constructive comments that helped improving the manuscript.

\section{References}

Adler RF, Markus MJ, Fenn DD. 1985. Detection of Severe Midwest Thunderstorms Using Geosynchronous Satellite Data. Monthly Weather Review 113: 769, doi:10.1175/1520-0493(1985)113;0769:DOSMTU;2.0.CO;2.

Alhammoud B, Claud C, Funatsu BM, Béranger K, Chaboureau JP. 2014. Patterns of precipitation and convection occurrence over the mediterranean basin derived from a decade of microwave satellite observations. Atmosphere 5(2): 370-398.

Argence S, Lambert D, Richard E, Chaboureau JP, Söhne N. 2008. Impact of initial condition uncertainties on the predictability of heavy rainfall in the mediterranean: a case study. Quarterly Journal of the Royal Meteorological Society 134(636): 1775-1788. 
Aumann HH, Ruzmaikin A. 2013. Frequency of deep convective clouds in the tropical zone from 10 years of AIRS data. Atmospheric Chemistry \& Physics 13: 10 795-10 806, doi:10.5194/acp-13-10795-2013.

Bechtold P, Bazile E, Guichard F, Mascart P, Richard E. 2001. A mass-flux convection scheme for regional and global models. Quarterly Journal of the Royal Meteorological Society 127: 869-886, doi:10.1002/qj.49712757309.

Bedka KM. 2011. Overshooting cloud top detections using MSG SEVIRI Infrared brightness temperatures and their relationship to severe weather over Europe. Atmospheric Research 99: 175-189, doi:10.1016/j.atmosres.2010.10.001.

Bedka KM, Dworak R, Brunner J, Feltz W. 2012. Validation of Satellite-Based Objective Overshooting Cloud-Top Detection Methods Using CloudSat Cloud Profiling Radar Observations. Journal of Applied Meteorology and Climatology 51: 1811-1822, doi:10.1175/JAMC-D-110131.1.

Bonsignori R. 2007. The Microwave Humidity Sounder (MHS): in-orbit performance assessment. In: Society of Photo-Optical Instrumentation Engineers (SPIE) Conference Series, Society of Photo-Optical Instrumentation Engineers (SPIE) Conference Series, vol. 6744. p. 0, doi: $10.1117 / 12.737986$

Bouniol D, Protat A, Plana-Fattori A, Giraud M, Vinson JP, Grand N. 2008. Comparison of Airborne and Spaceborne 95-GHz Radar Reflectivities and Evaluation of Multiple Scattering Effects in Spaceborne Measurements. Journal of Atmospheric and Oceanic Technology 25: 1983, doi: 10.1175/2008JTECHA1011.1.

Bousquet O, Smull BF. 2006. Observed mass transports accompanying upstream orographic blocking during map iop8. Quarterly Journal of the Royal Meteorological Society 132(620): 2393-2413.

Brunner JC, Ackerman SA, Bachmeier AS, Rabin RM. 2007. A Quantitative Analysis of the Enhanced-V Feature in Relation to Severe Weather. Weather and Forecasting 22: 853, doi:10.1175/WAF1022.1.

Burns BA, Wu X, Diak GR. 1997. Effects of precipitation and cloud ice on brightness temperatures in AMSU moisture channels. IEEE Transactions on Geoscience and Remote Sensing 35: 1429-1437, doi:10.1109/36.649797.

Buzzi A, Davolio S, Malguzzi P, Drofa O, Mastrangelo D. 2014. Heavy rainfall episodes over liguria of autumn 2011: numerical forecasting experiments. Natural Hazards and Earth System Sciences 14: 1325-1340, doi:10.5194/nhess-14-1325-2014.

Chaboureau JP, Bechtold P. 2005. Statistical representation of clouds in a regional model and the impact on the diurnal cycle of convection during Tropical Convection, Cirrus and Nitrogen Oxides (TROCCINOX). Journal of Geophysical Research (Atmospheres) 110(9): D17103, doi:10.1029/2004JD005645. 
Chaboureau JP, Claud C. 2006. Satellite-based climatology of Mediterranean cloud systems and their association with large-scale circulation. Journal of Geophysical Research (Atmospheres) 111: D01102, doi:10.1029/2005JD006460.

Chaboureau JP, Nuissier O, Claud C. 2012a. Verification of ensemble forecasts of Mediterranean high-impact weather events against satellite observations. Natural Hazards and Earth System Sciences 12: 2449-2462, doi:10.5194/nhess-12-2449-2012.

Chaboureau JP, Pantillon F, Lambert D, Richard E, Claud C. 2012b. Tropical transition of a Mediterranean storm by jet crossing. Quarterly Journal of the Royal Meteorological Society 138: 596-611, doi:10.1002/qj.960.

Chaboureau JP, Söhne N, Pinty JP, Meirold-Mautner I, Defer E, Prigent C, Pardo JR, Mech M, Crewell S. 2008. A Midlatitude Precipitating Cloud Database Validated with Satellite Observations. Journal of Applied Meteorology and Climatology 47: 1337, doi:10.1175/2007JAMC1731.1.

Clark H, Chaboureau JP. 2010. Uncertainties in short-term forecasts of a Mediterranean heavy precipitation event: Assessment with satellite observations. Journal of Geophysical Research (Atmospheres) 115(14): D22213, doi:10.1029/2010JD014388.

Claud C, Alhammoud B, Funatsu BM, Chaboureau JP. 2010. Mediterranean hurricanes: large-scale environment and convective and precipitating areas from satellite microwave observations. Natural Hazards and Earth System Science 10(10): 2199-2213, doi:10.5194/nhess-10-2199-2010.

Claud C, Alhammoud B, Funatsu BM, Lebeaupin Brossier C, Chaboureau JP, Béranger K, Drobinski P. 2012. A high resolution climatology of precipitation and deep convection over the Mediterranean region from operational satellite microwave data: development and application to the evaluation of model uncertainties. Natural Hazards and Earth System Sciences 12: 785-798, doi:10.5194/nhess-12-785-2012.

Cuxart J, Bougeault P, Redelsperger JL. 2000. A turbulence scheme allowing for mesoscale and large-eddy simulations. Quarterly Journal of the Royal Meteorological Society 126: 1-30, doi:10.1002/qj.49712656202.

Delanoë J, Protat A, Bouniol D, Heymsfield A, Bansemer A, Brown P. 2007. The Characterization of Ice Cloud Properties from Doppler Radar Measurements. Journal of Applied Meteorology and Climatology 46: 1682, doi:10.1175/JAM2543.1.

Delanoë J, Protat A, Jourdan O, Pelon J, Papazzoni M, Dupuy R, Gayet JF, Jouan C. 2013. Comparison of Airborne In Situ, Airborne Radar-Lidar, and Spaceborne Radar-Lidar Retrievals of Polar Ice Cloud Properties Sampled during the POLARCAT Campaign. Journal of Atmospheric and Oceanic Technology 30: 57-73, doi:10.1175/JTECH-D-11-00200.1.

Delanoë JME, Heymsfield AJ, Protat A, Bansemer A, Hogan RJ. 2014. Normalized particle size distribution for remote sensing application. Journal of Geophysical Research (Atmospheres) 119: 4204-4227, doi:10.1002/2013JD020700.

Delrieu G, Ducrocq V, Gaume E, Nicol J, Payrastre O, Yates E, Kirstetter PE, Andrieu H, Ayral PA, Bouvier C, Creutin JD, Livet M, Anquetin S, Lang M, Neppel L, Obled C, Parent Du Châtelet J, Saulnier GM, Walpersdorf A, Wobrock W. 2005. The Catastrophic Flash-Flood Event of 8 9 September 2002 in the Gard Region, France: A First Case Study for the Cévennes Vivarais Mediterranean Hydrometeorological Observatory. 
Journal of Hydrometeorology 6: 34, doi:10.1175/JHM-400.1.

Drobinski P, Ducrocq V, Alpert P, Anagnostou E, Borga M, Braud I, Chanzy A, Delrieu G, Estournel C, Boubrahmi NF, Font J, Grubisic V, Gualdi

S, Kottmeier C, Kotroni V, Lagouvardos K, Lionello P, Llasat MC, Ludwig W, Lutoff C, Mariotti A, Richard E, Romero R, Rotunno R, Roussot

O, Ruin I, Tintore J, Uijlenhoet R, Wernli H. 2014. HyMeX, a 10-year multidisciplinary program on the Mediterranean water cycle. Bulletin of the American Meteorological Society 5(24).

Ducrocq V, Braud I, Ferretti R, Davolio S, Flamant C, Jansa A, Kalthoff N, Taupier-letage I, Ayral Pa, Berne A, Borga M, Boudevillain B, Boichard J1, Bousquet O, Bouvier C, Chiggiato J, Cimini D, Coppola L, Cocquerez P, Defer E, Girolamo PD, Doerenbecher A, Dufournet Y, Gourley JJ, Labatut L, Lambert D, Frank S, Montani A, Nord G, Nuret M, Ramage K, Rison B, Roussot O, Schwarzenboeck A, Testor P, Tamayo J. 2014. HyMeX-SOP1, the field campaign dedicated to heavy precipitation and flash flooding in the northwestern Mediterranean. Bulletin of the American Meteorological Society 11: 1-59.

Ducrocq V, Nuissier O, Ricard D, Lebeaupin C, Thouvenin T. 2008. A numerical study of three catastrophic precipitating events over southern France. II: Mesoscale triggering and stationarity factors. Quarterly Journal of the Royal Meteorological Society 134: 131-145, doi: 10.1002/qj.199.

Ferretti R, Pichelli E, Gentile S, Maiello I, Cimini D, Davolio S, Miglietta MM, Panegrossi G, Baldini L, Pasi F, Marzano FS, Zinzi A, Mariani S, Casaioli M, Bartolini G, Loglisci N, Montani A, Marsigli C, Manzato A, Pucillo A, Ferrario ME, Colaiuda V, Rotunno R. 2014. Overview of the first HyMeX Special Observation Period over Italy: observations and model results. Hydrology and Earth System Sciences 18: 1953-1977, doi:10.5194/hess-18-1953-2014.

Fischer H, de Reus M, Traub M, Williams J, Lelieveld J, de Gouw J, Warneke C, Schlager H, Minikin A, Scheele R, Siegmund P. 2003. Deep convective injection of boundary layer air into the lowermost stratosphere at midlatitudes. Atmospheric Chemistry \& Physics 3: 739-745.

Fresnay S. 2014. Prévisibilité des épisodes météorologiques à fort impact: sensibilité aux anomalies d'altitude. PhD thesis, Université Paul SabatierToulouse III.

Funatsu BM, Claud C, Chaboureau JP. 2007. Potential of Advanced Microwave Sounding Unit to identify precipitating systems and associated upper-level features in the Mediterranean region: Case studies. Journal of Geophysical Research (Atmospheres) 112(11): D17113, doi: 10.1029/2006JD008297.

Funatsu BM, Claud C, Chaboureau JP. 2008. A 6-year AMSU-based climatology of upper-level troughs and associated precipitation distribution in the Mediterranean region. Journal of Geophysical Research (Atmospheres) 113(12): D15120, doi:10.1029/2008JD009918. 
Funatsu BM, Claud C, Chaboureau JP. 2009. Comparison between the Large-Scale Environments of Moderate and Intense Precipitating Systems in the Mediterranean Region. Monthly Weather Review 137: 3933, doi:10.1175/2009MWR2922.1.

Funatsu BM, Dubreuil V, Claud C, Arvor D, Gan MA. 2012. Convective activity in Mato Grosso state (Brazil) from microwave satellite observations: Comparisons between AMSU and TRMM data sets. Journal of Geophysical Research (Atmospheres) 117(16): D16109, doi: 10.1029/2011JD017259.

Geer A, Baordo F. 2014. Improved scattering radiative transfer for frozen hydrometeors at microwave frequencies. Atmospheric Measurement Techniques 7(6): 1839-1860.

Hegglin M, Brunner D, Wernli H, Schwierz C, Martius O, Hoor P, Fischer H, Parchatka U, Spelten N, Schiller C, et al. 2004. Tracing troposphereto-stratosphere transport above a mid-latitude deep convective system. Atmospheric Chemistry and Physics 4(3): 741-756.

Homeyer CR, Kumjian MR. 2014. Microphysical characteristics of overshooting convection from polarimetric radar observations. Journal of the Atmospheric Sciences (2014).

Homeyer CR, Pan LL, Dorsi SW, Avallone LM, Weinheimer AJ, O’Brien AS, DiGangi JP, Zondlo MA, Ryerson TB, Diskin GS, et al. 2014. Convective transport of water vapor into the lower stratosphere observed during double-tropopause events. Journal of Geophysical Research: Atmospheres 119(18): 10-941.

Hong G, Heygster G, Miao J, Kunzi K. 2005. Detection of tropical deep convective clouds from AMSU-B water vapor channels measurements. Journal of Geophysical Research (Atmospheres) 110: D05205, doi:10.1029/2004JD004949.

Hong G, Heygster G, Notholt J, Buehler SA. 2008. Interannual to Diurnal Variations in Tropical and Subtropical Deep Convective Clouds and Convective Overshooting from Seven Years of AMSU-B Measurements. Journal of Climate 21: 4168, doi:10.1175/2008JCLI1911.1.

Kömüş̧̧ї AM. 1998. Analysis of meteorological and terrain features leading to the izmir flash flood, 3-4 november 1995. Natural hazards 18(1): $1-25$.

Kotroni V, Lagouvardos K, Kallos G, Ziakopoulos D. 1999. Severe flooding over central and southern greece associated with pre-cold frontal orographic lifting. Quarterly Journal of the Royal Meteorological Society 125(555): 967-991.

Lafore JP, Stein J, Asencio N, Bougeault P, Ducrocq V, Duron J, Fischer C, Héreil P, Mascart P, Masson V, Pinty JP, Redelsperger JL, Richard E, Vilà-Guerau de Arellano J. 1998. The Meso-NH Atmospheric Simulation System. Part I: adiabatic formulation and control simulations. Annales Geophysicae 16: 90-109, doi:10.1007/s00585-997-0090-6.

Lagouvardos K, Kotroni V, Defer E. 2007. The 21-22 january 2004 explosive cyclogenesis over the aegean sea: observations and model analysis. Quarterly Journal of the Royal Meteorological Society 133(627): 1519-1531. 
Lionello P, Bhend J, Buzzi A, Della-Marta P, Krichak S, Jansa A, Maheras P, Sanna A, Trigo I, Trigo R. 2006. Cyclones in the mediterranean region: climatology and effects on the environment. Mediterranean climate variability. Elsevier, Amsterdam : 325-372.

Masson V, Le Moigne P, Martin E, Faroux S, Alias A, Alkama R, Belamari S, Barbu A, Boone A, Bouyssel F, Brousseau P, Brun E, Calvet JC, Carrer D, Decharme B, Delire C, Donier S, Essaouini K, Gibelin AL, Giordani H, Habets F, Jidane M, Kerdraon G, Kourzeneva E, Lafaysse M, Lafont S, Lebeaupin Brossier C, Lemonsu A, Mahfouf JF, Marguinaud P, Mokhtari M, Morin S, Pigeon G, Salgado R, Seity Y, Taillefer F, Tanguy G, Tulet P, Vincendon B, Vionnet V, Voldoire A. 2013. The SURFEXv7.2 land and ocean surface platform for coupled or offline simulation of earth surface variables and fluxes. Geoscientific Model Development 6: 929-960, doi:10.5194/gmd-6-929-2013.

Melani S, Pasi F, Gozzini B, Ortolani A. 2013. A four year (2007-2010) analysis of long-lasting deep convective systems in the Mediterranean basin. Atmospheric Research 123: 151-166, doi:10.1016/j.atmosres.2012.09.006.

Miglietta M, Laviola S, Malvaldi A, Conte D, Levizzani V, Price C. 2013. Analysis of tropical-like cyclones over the mediterranean sea through a combined modeling and satellite approach. Geophysical Research Letters 40(10): 2400-2405.

Mlawer EJ, Taubman SJ, Brown PD, Iacono MJ, Clough SA. 1997. Radiative transfer for inhomogeneous atmospheres: RRTM, a validated correlated-k model for the longwave. Journal of Geophysical Research 102: 16663, doi:10.1029/97JD00237.

Negri AJ, Adler RF. 1981. Relation of Satellite-Based Thunderstorm Intensity to Radar-Estimated Rainfall. Journal of Applied Meteorology 20: 288-300, doi:10.1175/1520-0450(1981)020¡0288:ROSBTI $\dot{i} 2.0 . C O ; 2$.

Orlanski I. 1975. A rational subdivision of scales for atmospheric processes. Bulletin of the American Meteorological Society 56(5): 527-530.

Papagiannaki K, Lagouvardos K, Kotroni V. 2013. A database of high-impact weather events in Greece: a descriptive impact analysis for the period 2001-2011. Natural Hazards and Earth System Sciences 13: 727-736, doi:10.5194/nhess-13-727-2013.

Pergaud J, Masson V, Malardel S, Couvreux F. 2009. A Parameterization of Dry Thermals and Shallow Cumuli for Mesoscale Numerical Weather Prediction. Boundary-Layer Meteorology 132: 83-106, doi:10.1007/s10546-009-9388-0.

Pinty J, Jabouille P. 1998. A mixed-phase cloud parameterization for use in mesoscale non-hydrostatic model: simulations of a squall line and of orographic precipitations. In: Conf. on Cloud Physics. pp. 217-220.

Poulida O, Dickerson RR, Heymsfield A. 1996. Stratosphere-troposphere exchange in a midlatitude mesoscale convective complex: 1. Observations. Journal of Geophysical Research 101: 6823-6836, doi:10.1029/95JD03523.

Protat A, Bouniol D, Delanoë J, May PT, Plana-Fattori A, Hasson A, O’Connor E, Görsdorf U, Heymsfield AJ. 2009. Assessment of Cloudsat Reflectivity Measurements and Ice Cloud Properties Using Ground-Based and Airborne Cloud Radar Observations. Journal of Atmospheric and Oceanic Technology 26: 1717, doi:10.1175/2009JTECHA1246.1. 
Protat A, Pelon J, Grand N, Delville P, Laborie P, Vinson JP, Bouniol D, Bruneau D, Chepfer H, Delanoë J, et al. 2004. Le projet rali: Combinaison d'un radar et d'un lidar pour l'étude des nuages faiblement précipitants. La Météorologie 47, doi:10.4267/2042/36076.

Raveh-Rubin S, Wernli H. 2015. Large-scale wind and precipitation extremes in the mediterranean - a climatological analysis for 1979-2012. Quarterly Journal of the Royal Meteorological Society: n/a-n/adoi:10.1002/qj.2531, URL http: //dx. doi.org/10.1002/qj.2531.

Rebora N, Molini L, Casella E, Comellas A, Fiori E, Pignone F, Siccardi F, Silvestro F, Tanelli S, Parodi A. 2013. Extreme Rainfall in the Mediterranean: What Can We Learn from Observations? Journal of Hydrometeorology 14: 906-922, doi:10.1175/JHM-D-12-083.1.

Reynolds DW. 1980. Observations of damaging hailstorms from geosynchronous satellite digital data. Monthly Weather Review 108(3): 337-348.

Roth G, Barrett E, Giuli D, Goddard J, Llasat M, Minciardi R, Mugnai A, Scarchilli G, Siccardi F. 1996. The storm project: Aims, objectives and organisation. Remote Sensing Reviews 14(1-3): 23-50.

Rotunno R, Ferretti R. 2003. Orographic effects on rainfall in map cases iop 2b and iop 8. Quarterly Journal of the Royal Meteorological Society 129(588): 373-390.

Sanò P, Panegrossi G, Casella D, Di Paola F, Milani L, Mugnai A, Petracca M, Dietrich S. 2015. The passive microwave neural network precipitation retrieval (pnpr) algorithm for amsu/mhs observations: description and application to european case studies. Atmospheric Measurement Techniques 8(2): 837-857.

Saunders R, Matricardi M, Brunel P, English S, Bauer P, O Keeffe U, Francis P, Rayer P. 2005. Rttov-8 science and validation report. NWP SAF Report 41.

Schmetz J, Pili P, Tjemkes S, Just D, Kerkmann J, Rota S, Ratier A. 2002. An Introduction to Meteosat Second Generation (MSG). Bulletin of the American Meteorological Society 83: 977-992, doi:10.1175/1520-0477(2002)083;0977:AITMSG;2.3.CO;2.

Sénési S, Bougeault P, Chèze JL, Cosentino P, Thepenier RM. 1996. The Vaison-La-Romaine Flash Flood: Mesoscale Analysis and Predictability Issues. Weather and Forecasting 11: 417-442, doi:10.1175/1520-0434(1996)011;0417:TVLRFFi2.0.CO;2.

Siccardi F. 1996. Rainstorm hazards and related disasters in the north-west mediterranean region. Remote Sensing Reviews 14(1-3): 5-21.

Silvestro F, Gabellani S, Giannoni F, Parodi A, Rebora N, Rudari R, Siccardi F. 2012. A hydrological analysis of the 4 November 2011 event in Genoa. Natural Hazards and Earth System Sciences 12: 2743-2752, doi:10.5194/nhess-12-2743-2012.

Söhne N, Chaboureau JP, Guichard F. 2008. Verification of cloud cover forecast with satellite observation over west africa. Monthly Weather Review 136(11): 4421-4434. 
Stein J, Richard E, Lafore JP, Pinty JP, Asencio N, Cosma S. 2000. High-Resolution Non-Hydrostatic Simulations of Flash-Flood Episodes with Grid-Nesting and Ice-Phase Parameterization. Meteorology and Atmospheric Physics 72: 203-221, doi:10.1007/s007030050016.

Tous M, Romero R. 2013. Meteorological environments associated with medicane development. International Journal of Climatology 33: 1-14, doi:10.1002/joc.3428.

Trigo IF, Bigg GR, Davies TD. 2002. Climatology of Cyclogenesis Mechanisms in the Mediterranean. Monthly Weather Review 130: 549, doi: 10.1175/1520-0493(2002)130;0549:COCMIT $\dot{i} 2.0 . C O ; 2$.

Varble A, Zipser EJ, Fridlind AM, Zhu P, Ackerman AS, Chaboureau JP, Collis S, Fan J, Hill A, Shipway B. 2014. Evaluation of cloud-resolving and limited area model intercomparison simulations using twp-ice observations: 1. deep convective updraft properties. Journal of Geophysical Research: Atmospheres 119(24): 13-891.

Wang JR, Zhan J, Racette P. 1997. Storm-Associated Microwave Radiometric Signatures in the Frequency Range of 90220 GHz. Journal of Atmospheric and Oceanic Technology 14: 13, doi:10.1175/1520-0426(1997)014;0013:SAMRSI $; 2.0 . C O ; 2$. 